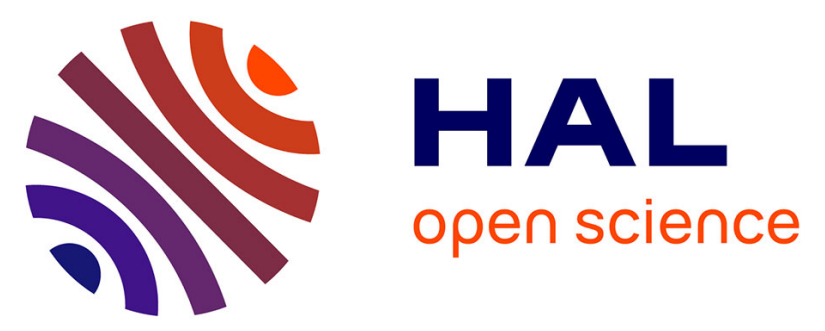

\title{
Electrochemical mineralization of sulfamethoxazole over wide pH range using FeIIFeIII LDH modified carbon felt cathode: Degradation pathway, toxicity and reusability of the modified cathode.
}

\author{
Soliu O. Ganiyu, Thi Xuan Huong Le, Mikhael Bechelany, Nihal Oturan, \\ Stefano Papirio, Giovanni Esposito, Eric D. van Hullebusch, Marc Cretin, \\ Mehmet A. Oturan
}

\section{- To cite this version:}

Soliu O. Ganiyu, Thi Xuan Huong Le, Mikhael Bechelany, Nihal Oturan, Stefano Papirio, et al.. Electrochemical mineralization of sulfamethoxazole over wide $\mathrm{pH}$ range using FeIIFeIII LDH modified carbon felt cathode: Degradation pathway, toxicity and reusability of the modified cathode.. Chemical Engineering Journal, 2018, 350, pp.844-855. 10.1016/j.cej.2018.04.141 · hal-01805064

\section{HAL Id: hal-01805064 https://hal.science/hal-01805064}

Submitted on 4 Jun 2021

HAL is a multi-disciplinary open access archive for the deposit and dissemination of scientific research documents, whether they are published or not. The documents may come from teaching and research institutions in France or abroad, or from public or private research centers.
L'archive ouverte pluridisciplinaire HAL, est destinée au dépôt et à la diffusion de documents scientifiques de niveau recherche, publiés ou non, émanant des établissements d'enseignement et de recherche français ou étrangers, des laboratoires publics ou privés. 
Electrochemical mineralization of sulfamethoxazole over wide $\mathrm{pH}$ range using $\mathrm{Fe}^{\mathrm{II}} \mathrm{Fe}^{\mathrm{III}}$

LDH modified carbon felt cathode: Degradation pathway, toxicity and reusability of the modified cathode

Soliu O. Ganiyu ${ }^{1}$, Thi Xuan Huong Le ${ }^{2}$, Mikhael Bechelany ${ }^{2, *}$, Nihal Oturan ${ }^{1}$, Stefano Papirio $^{3}$, Giovanni Esposito ${ }^{4}$, Eric van Hullebusch ${ }^{5}$, Marc Cretin $^{2}$, Mehmet A. Oturan ${ }^{1 *}$

${ }^{1}$ Université Paris-Est, Laboratoire Géomatériaux et Environnement (LGE), EA 4508, UPEM, 77454 Marne-la-Vallée, France

${ }^{2}$ IEM (Institut Européen des Membranes), UMR 5635, CNRS, ENSCM, UM, Université de Montpellier, Place E. Bataillon, F-34095 Montpellier, Cedex 5, France

${ }^{3}$ Department of Civil, Architectural and Environmental Engineering, University of Napoli Federico II, Via Claudio 21, 80125 Napoli, Italy

${ }^{4}$ Department of Civil and Mechanical Engineering, University of Cassino and Southern Lazio, Via Di Biasio 43, 03043 Cassino (FR), Italy

${ }^{5}$ IHE Delft, Institute for Water Education, Westvest 7, 2611 AX Delft, The Netherlands

\section{Manuscript submitted to the Chemical Engineering Journal}


* Corresponding author's emails:

mikhael.bechelany@umontpellier.fr (MikhaelBechelany)

mehmet.oturan@u-pem.fr(Mehmet A. Oturan)

\begin{abstract}
Hierarchical three-dimensional (3D) porous architecture $\mathrm{Fe}^{\mathrm{II}} \mathrm{Fe}^{\mathrm{III}}$ layered double hydroxide (LDH) multiwall was grown on carbon-felt (CF) substrate via solvothermal process. The asdeposited $\mathrm{Fe}^{\mathrm{II}} \mathrm{Fe}^{\mathrm{III}}$ LDH/CF cathode was composed of highly oriented and well crystallized interconnected nanowalls with high electrical conductivity and excellent catalytic activity over a wide $\mathrm{pH}$ range $(\mathrm{pH} 3-9)$ for heterogeneous electro-Fenton (HEF) degradation of antibiotic sulfamethoxazole (SMT) in aqueous medium. Mineralization efficiencies (in terms of TOC removal) of $\sim 97 \%, 93 \%$ and $90 \%$ was achieved at $\mathrm{pH} 3,6$ and 9 respectively for $\mathrm{Fe}^{\mathrm{II}} \mathrm{Fe}^{\mathrm{III}}$ cathode during HEF treatment of $0.2 \mathrm{mM} \mathrm{SMT} \mathrm{solution} \mathrm{at} \mathrm{applied} \mathrm{current} \mathrm{density} \mathrm{of} 7.5 \mathrm{~mA} \mathrm{~cm} \mathrm{~cm}^{-2}$ using $\mathrm{Ti}_{4} \mathrm{O}_{7}$ anode. Comparative electro-Fenton $\left(\mathrm{EF}^{-\mathrm{Fe}^{2+}}\right.$ ) with $0.2 \mathrm{mM} \mathrm{Fe}{ }^{2+}$ or electrooxidation with $\mathrm{H}_{2} \mathrm{O}_{2}$ production $\left(\mathrm{EO}-\mathrm{H}_{2} \mathrm{O}_{2}\right)$ studies using raw $\mathrm{CF}$ cathode at similar experimental conditions showed relatively lower mineralization with highest TOC removal efficiency of $77 \%$ and $64 \%$ obtained at $\mathrm{pH} 3$ for $\mathrm{EF}-\mathrm{Fe}^{2+}$ and $\mathrm{EO}-\mathrm{H}_{2} \mathrm{O}_{2}$ respectively. Oxidative degradation of SMT in HEF system was by (i) $\mathrm{Ti}_{4} \mathrm{O}_{7}\left({ }^{\bullet} \mathrm{OH}\right)$ generated at anode surface at all $\mathrm{pH}$ studied, (ii) surface catalyzed process and (iii) contribution from homogeneous catalyzed process at $\mathrm{pH} 3$ due to leached iron ions. The prepared $\mathrm{Fe}^{\mathrm{II}} \mathrm{Fe}^{\mathrm{III}} \mathrm{LDH} / \mathrm{CF}$ exhibited excellent catalytic stability with good reusability up to 10 cycles of $4 \mathrm{~h}$ treatment at $\mathrm{pH}$ 6. Initial SMT solution showed relatively high toxicity but total detoxification of the solution was attained after $8 \mathrm{~h}$ of treatment by HEF with
\end{abstract}


$\mathrm{Fe}^{\mathrm{II}} \mathrm{Fe}{ }^{\mathrm{III}} \mathrm{LDH} / \mathrm{CF}$ cathode. HEF with $\mathrm{Fe}^{\mathrm{II}} \mathrm{Fe}^{\mathrm{III}} \mathrm{LDH} / \mathrm{CF}$ cathode is an exciting technique for remediation of organic contaminated wastewater.

Keywords: $\mathrm{Fe}^{\mathrm{II}} \mathrm{Fe}^{\mathrm{III}} \mathrm{LDH}$ modified carbon felt, heterogeneous electro-Fenton, catalytic activity, Sulfamethoxazole, mineralization, Microtox ${ }^{\circledR}$ toxicity 


\section{Introduction}

Nowadays, electrochemical advanced oxidation processes (EAOPs) receive increasing attention due to their excellent potential for total destruction of refractory organic pollutants in wastewater [1-4]. Although, there are still few skepticism surrounding it full implemented on industrial scale due to the lack of technology certification and limited large-scale applications, the potential of the process has received the attention of some industrial players, who are currently perfecting the engineering design and operational parameters optimization for efficient and profitable industrial scale usage [5]. These eco-friendly wastewater treatment techniques utilize on-site generated reactive oxygen species, mostly hydroxyl radicals $\left({ }^{\bullet} \mathrm{OH}\right)$, which is the second strongest oxidizing species after fluorine $\left(E^{o}\left({ }^{\circ} \mathrm{OH} / \mathrm{H}_{2} \mathrm{O}\right)=2.80 \mathrm{~V} / \mathrm{SHE}\right)$ and can nonselectively oxidize organic pollutants until their total mineralization (electrochemical combustion) to $\mathrm{CO}_{2}$, water and inorganic ions [6-9]. EAOPs based on Fenton's chemistry (electro-Fenton and related process) are one of the most widely studied techniques among EAOPs for wastewater treatment $[2,3]$. In electro-Fenton process $(\mathrm{EF}),{ }^{\bullet} \mathrm{OH}$ are continuously produced via the reaction between electrochemically generated Fenton's reagent $\left(\mathrm{H}_{2} \mathrm{O}_{2}+\mathrm{Fe}^{2+}\right)$ (eq. 1) in the bulk solution $[2,3,6,8]$. The required $\mathrm{H}_{2} \mathrm{O}_{2}$ is continuously electrogenerated on-site by the reduction of $\mathrm{O}_{2}$ at the cathode (eq. 2) and only small amount of $\mathrm{Fe}^{2+}$ is added to catalyze its decomposition,thanksto continuousFe ${ }^{2+}$ production from the $\mathrm{Fe}^{3+}$ produced in Fenton's reaction (eq.1) by electro-reduction at the cathode (eq. 3) $[2,3,10]$.

$$
\begin{aligned}
& \mathrm{Fe}^{2+}+\mathrm{H}_{2} \mathrm{O}_{2}+\mathrm{H}^{+} \rightarrow \mathrm{Fe}^{3+}+\mathrm{H}_{2} \mathrm{O}+{ }^{\circ} \mathrm{OH} \\
& \mathrm{O}_{2}+2 \mathrm{H}^{+}+2 \mathrm{e}^{-} \rightarrow \mathrm{H}_{2} \mathrm{O}_{2} \\
& \mathrm{Fe}^{3+}+\mathrm{e}^{-} \rightarrow \mathrm{Fe}^{2+}
\end{aligned}
$$


However, some major challenges are commonly encountered when usingconventional EF process. For instance EF is only optimal at very narrow $\mathrm{pH}$ range ( $\mathrm{pH} 2.5-3.5)$, as such working outside this $\mathrm{pH}$ drastically reduces the efficiency of the process[11-14]. This is not beneficial when treating real industrial effluents/wastewater, which usually have divergent $\mathrm{pH}$ depending on the origin. Further, the catalyst in conventional EF has limited recyclability and reusability and effluent must be neutralized before disposal to nullify the acidic condition, which may also results in generation of sludge that may require a secondary process for its disposal $[11,13]$.

Heterogeneous EF (HEF) process has been developed to overcome these challenges since it is effective over a wide $\mathrm{pH}$ range, including basic $\mathrm{pH}$, with recyclability of the solid catalyst [13]. Also, the need for post-treatment neutralization and formation of iron-rich sludge encounter in conventional EF system is completely eliminated with the use of solid catalyst. Based on literature, heterogeneous catalysts such as natural Fe minerals [15-19], supported transition metal/metal oxides [11,20-24], and transition metals doped - carbon aerogel [25-28] have been studied for degradation of the various class of organic pollutants. Excellent mineralization of organics as a result of both homogeneous and surface catalyzed process has been reported for iron containing minerals as heterogeneous catalysts in HEF especially at acid $\mathrm{pH}$, however such system demonstrated low recyclability. Fe/Fe-oxides supported on micro/mesoporous materials have been reported to show high adsorption property for some pollutants which hinders and delays their catalytic degradation by HEF process [29]. Although studies have shown that carbon aerogel doped withtransition metals/oxides exhibited high catalytic activity and reusability over wide $\mathrm{pH}$ range; theirintricate and multi-steps preparation route seemsuneconomical for large scale production $[25,26]$. Recently we reported excellent performance of CoFe-layered double hydroxide (LDH) modified carbon-felt cathode for mineralization of acid-orange II [14], but the 
use of $\mathrm{Cu}$ and $\mathrm{Co}$ as catalyst in $\mathrm{HEF}$ is detrimental because both are considered toxic. In fact, leaching of $\mathrm{Co}$ or $\mathrm{Cu}$ at acidic and neutral $\mathrm{pH}$ has been reported for doped carbon aerogel and LDH applied in HEF process [14,25,26,30].

SMT is one of the most widely used sulfonamide antibiotics against aerobic bacteria and protozoa and its combination with other antibiotics is largely administered for the treatment of respiratory disease like pneumonia [31,32]. Several studies have reported the occurrence of SMT at different concentration levels (ng $\mathrm{L}^{-1}$ to $\mu \mathrm{g} \mathrm{L}^{-1}$ ) in various municipal sewage treatment plants (STPs), surface water and even drinking water, however higher concentration levels could be found in untreated hospital effluents, animal impoundments and wastewater effluents from pharmaceutical plants $[33,34]$. Similarto other pharmaceuticals, the presence of SMT has become a serious environmental concern due to its continuous accumulation and resistance to natural attenuation processes [35]. SMT is refractory to the conventional treatment used in STPs, but many advanced oxidation processes (AOPs) have been applied as an alternative treatment for the degradation of SMT[32]. Among the AOPs, EAOPs such as electrooxidation (EO) and EF have been reported to achieve excellent decontamination of SMT solution $[31,32,35]$.

In this study, $\mathrm{Fe}^{\mathrm{II}} \mathrm{Fe}^{\mathrm{III}}$ was deposited on $\mathrm{CF}$ by solvothermal process. The prepared cathode was characterized by X-ray diffraction (XRD) measurement, Scanning electron microscopy (SEM), Fourier-transform infrared spectroscopy (FTIR), X-ray photoelectron spectroscopy (XPS) and Electrochemical impedance spectroscopy (EIS) to examineitstructural and electrochemical properties. The catalytic activity of the $\mathrm{Fe}^{\mathrm{II}} \mathrm{Fe}^{\mathrm{III}} \mathrm{LDH}$ modified $\mathrm{CF}$ cathode for total decontamination of synthetic organic polluted wastewater was evaluated by studying the HEF mineralization of SMT (as model pollutants) at $\mathrm{pH} 3-9$. Besides, sub-stoichiometric titanium oxide $\left(\mathrm{Ti}_{4} \mathrm{O}_{7}\right)$ was used as the anode material. This electrode has been demonstrated to 
be efficient in electrochemical wastewater treatment and capable of producing heterogeneous hydroxyl radical $\left(\mathrm{Ti}_{4} \mathrm{O}_{7}\left({ }^{\bullet} \mathrm{OH}\right)\right)$ at it surface via water oxidation (eq. 4) for mineralization of organics, which can contribute to the overall efficiency of the HEF process[36-38].

$\mathrm{Ti}_{4} \mathrm{O}_{7}+\mathrm{H}_{2} \mathrm{O} \rightarrow \mathrm{Ti}_{4} \mathrm{O}_{7}(\bullet \mathrm{OH})+\mathrm{H}^{+}+\mathrm{e}^{-}$

In addition, the evolution of the toxicity of the SMT solution during the HEF treatment was examined using Microtox® method.

\section{Materials and methods}

\subsection{Chemicals}

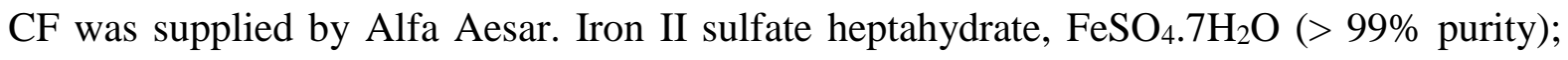
iron III nitrate nonahydrate, $\mathrm{Fe}\left(\mathrm{NO}_{3}\right)_{3} .9 \mathrm{H}_{2} \mathrm{O}$ (98\% purity); urea, $\mathrm{CO}\left(\mathrm{NH}_{2}\right)_{2}$ and ammonium fluoride, $\mathrm{NH}_{4} \mathrm{~F}$ (99\% purity) were purchased from Sigma Aldrich and utilizedas-supplied for the preparation of LDH deposited on the CF. SMT, $\mathrm{C}_{10} \mathrm{H}_{11} \mathrm{~N}_{3} \mathrm{O}_{3} \mathrm{~S}$ and sodium sulfate, $\mathrm{Na}_{2} \mathrm{SO}_{4}$ (anhydrous, 99-100\%) were also supplied by Sigma Aldrich. Bioluminescent bacteria Vibrio fischeri and the activation reagent LCK 487 LUMISTOX used in Microtox ${ }^{\circledR}$ were supplied by Hach Lange France SAS. All solutions were prepared with ultra-pure water obtained from a Millipore Mill-Q system $(\mathrm{R}>18 \mathrm{M} \Omega \mathrm{cm})$. Organic solvents and other chemicals used were either HPLC or analytic grade from Sigma-Aldrich, Fluka and Merck.

\subsection{Electrode preparation}


The $\mathrm{Fe}^{\mathrm{II}} \mathrm{Fe}^{\mathrm{III}} \mathrm{LDH} / \mathrm{CF}$ cathode was produced by in-situ solvothermal process using Teflon lining autoclave [14,39-41]. Growth solution was made by dissolving $\mathrm{FeSO}_{4} .7 \mathrm{H}_{2} \mathrm{O}(25 \mathrm{mM})$, $\mathrm{Fe}_{2}\left(\mathrm{NO}_{3}\right)_{3} .9 \mathrm{H}_{2} \mathrm{O}(12.5 \mathrm{mM}), \mathrm{NH}_{4} \mathrm{~F}(125 \mathrm{mM})$ and $\mathrm{CO}\left(\mathrm{NH}_{2}\right)_{2}(0.5 \mathrm{M})$ in $75 \mathrm{~mL}$ of ultra-pure water. A $6 \mathrm{~cm} \times 1 \mathrm{~cm} \times 1.27 \mathrm{~cm} \mathrm{CF}$ was pretreated with concentrated $\mathrm{HNO}_{3}$, clean thoroughly using ultrasonication, in a bath containing deionized water, acetone, ethanol and deionized water in the sequence order. Subsequently, the pretreated CF and the homogeneous growth solution was transferred into a Teflon-lined stainless steel autoclave for hydrothermal treatment at $\sim 100$ ${ }^{0} \mathrm{C}$. The $\mathrm{CF}$ coated with $\mathrm{LDH}$ and the $\mathrm{LDH}$ particles were carefully removed from the solution, thoroughly washed with water and dried at $60{ }^{\circ} \mathrm{C}$. The mass-loading of $\mathrm{Fe}^{\mathrm{II}} \mathrm{Fe}^{\mathrm{III}} \mathrm{LDH}$ coating was accurately measured from the weight difference of dried clean substrate before and after the growth; and the average loading was $0.6 \pm 0.02 \mathrm{mg} \mathrm{cm}^{-2}$.

\subsection{Electrode characterization}

The SEM micrographs of as-prepared cathode weretaken using Hitachi S-4800 microscope. The XRD patterns were collectedusing a BRUKER S5000 diffractometer, using $\mathrm{Cu}$ $\mathrm{K} \alpha$ radiation $(0.15418 \mathrm{~nm})$ at $40 \mathrm{kV}$ and $20 \mathrm{~mA}$. FTIR Spectra of the powder LDH was performed on NEXUS FTIR (ThermoFisher). The XPS spectra of the LDH were collected on

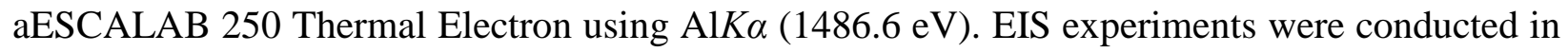
$50 \mathrm{mM} \mathrm{Na} 2 \mathrm{SO}_{4}$ solution using $\mu 3$ AUT70466 Autolab System with a three-electrode cell. The working electrode was the modified CF, whereas Pt foil and Standard Calomel Electrode were used as a counter and reference electrode respectively. Electrical conductivity of the prepared $\mathrm{Fe}^{\mathrm{II}} \mathrm{Fe}^{\mathrm{III}} \mathrm{LDH} / \mathrm{CF}$ was determined by measuring the electrode interfacial charge-transfer 
resistance $\left(\mathrm{R}_{\mathrm{t}}\right)$ using EIS spectra. The impedance spectra were recorded at the open circuit voltage inthe range of $50 \mathrm{kHz}$ to $100 \mathrm{MHz}$ and voltage amplitude of $10 \mathrm{mV}$.

\subsection{EF experiment}

The EF trials were conducted in an undivided cylindrical reactor of diameter $4 \mathrm{~cm}$ and $150 \mathrm{~mL}$ volume equipped with $24 \mathrm{~cm}^{2}$ thin film $\mathrm{Ti}_{4} \mathrm{O}_{7}$ anode (Saint Gobain C.R.E.E., France), placed in parallel to the cathode $(4.5 \mathrm{~cm} \times 1 \mathrm{~cm} \times 1.27 \mathrm{~cm})$ made of $\mathrm{Fe}^{\mathrm{II}} \mathrm{Fe}{ }^{\mathrm{III}} \mathrm{LDH} / \mathrm{CF}$ at approximately $2 \mathrm{~cm}$ inter-electrode distance. Single chamber electrochemical cells are easy to operate and the parameters can be easily scale-up to pre-pilot or pilot scale. All electrolyses were carried out with $145 \mathrm{~mL}$ SMT solutions $(0.2 \mathrm{mM})$ containing $0.05 \mathrm{M} \mathrm{Na}_{2} \mathrm{SO}_{4}$ as background electrolyte with constant stirringusing a PTFE magnetic bar. Compressed air was continuously sparged into the reactor at about $1 \mathrm{~L} \mathrm{~min}^{-1}$, starting at $10 \mathrm{~min}$ before electrolysis to ensure a stationary $\mathrm{O}_{2}$ concentration level. The use of compressed air is normally prefer to pure $\mathrm{O}_{2}$ especially when using cathode materials with high potential for $\mathrm{O}_{2}$ reduction reaction such as carbon-felt because of economic advantage and possible scale-up of the process. For comparison, analogous experiments were performed with raw carbon-felt cathode of similar size with the

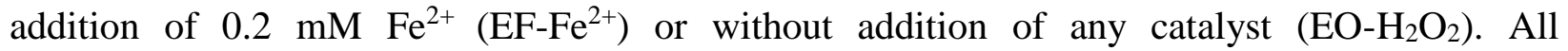
electrochemical experiments were performed in duplicate and average values were reported with corresponding error bar.

\subsection{Instruments and analytic procedures}


All experiments were conducted with a Hameg HM7042-5 triple power supply at constant current density of $7.5 \mathrm{~mA} \mathrm{~cm}{ }^{-2}$. The SMT solution $\mathrm{pH}$ was adjusted with $1 \mathrm{M} \mathrm{H}_{2} \mathrm{SO}_{4}$ or $\mathrm{NaOH}$ and was recorded on a CyberScan $\mathrm{pH} 1500 \mathrm{pH}-$ meter from Eutech Instruments. The mineralization of the SMT solutions was assessed from the decay of its total organic carbon (TOC). The TOC of samples were analyzed on a Shimadzu TOC-L CSH/CSN analyzer. Reproducible TOC values with $\pm 2 \%$ accuracy were found by injecting $50 \mu \mathrm{L}$ aliquots into the analyzer. Percentage of TOC removal was calculated from to the following equation:

TOC removal $(\%)=\frac{\Delta(\mathrm{TOC})_{\exp }}{\mathrm{TOC}_{0}} \times 100$

where $\Delta$ (TOC) $)_{\exp }$ is the TOC decay at time $\mathrm{t}\left(\mathrm{mg} \mathrm{L}^{-1}\right)$ and $\mathrm{TOC}_{\mathrm{o}}$ is the corresponding initial value before electrolysis (in same unity).

The decay of SMT concentration was followed by injecting $20 \mu \mathrm{L}$ aliquots to the reversed-phase high performance liquid chromatography (HPLC) (Dionex) equipped with P680 HPLC pump and fitted with a Purosher RP-18, $5 \mu \mathrm{m}, 25 \mathrm{~cm} \times 4.6 \mathrm{~mm}$ (i.d.) column at $40{ }^{\circ} \mathrm{C}$. Detection was done with a UVD340U photodiode array detector selected at $\lambda=270 \mathrm{~nm}$. Isocratic solvent mixture of methanol/water (containing $\left.1 \% \mathrm{H}_{3} \mathrm{PO}_{4}\right)$ 25:75 (v/v) was used as mobile phase at a flow rate of $0.8 \mathrm{~mL} \mathrm{~min}{ }^{-1}$. The quantity of $\mathrm{Fe}^{2+}$ and total $\mathrm{Fe}$ leached into the treated solution from the $\mathrm{Fe}^{\mathrm{II}} \mathrm{Fe} \mathrm{FII}^{\mathrm{III}} \mathrm{LDH} / \mathrm{CF}$ cathode at $\mathrm{pH} 3,6$ and 9 was estimated by colorimetric technique in accordance with recipe reported elsewhere [42].

Short-chain carboxylic acids formed during the HEF treatment at pH 3 with $\mathrm{Fe}^{\mathrm{II}} \mathrm{Fe}^{\mathrm{III}}$ LDH/CF cathode were analyzed by ion-exclusion HPLC (Merck Lachrom) equipped with a L2130 pump, a C18 Acclaim OA, $4 \mathrm{~mm} \times 25 \mathrm{~cm}$ (i.d.) column at $40{ }^{\circ} \mathrm{C}$, and a L-2400 UV detector operated at $\lambda=210 \mathrm{~nm}$, using $1 \% \mathrm{H}_{2} \mathrm{SO}_{4}$ at $0.2 \mathrm{~mL} \mathrm{~min}^{-1}$ as mobile phase. Aromatic 
intermediates produced after $30 \mathrm{~min}$ of $\mathrm{HEF}$ treatment of $0.5 \mathrm{mM}$ SMT solutions at $\mathrm{pH} 3$ were identified by GC-MS using Trace 1300 gas chromatograph-Single Quadrupole ISQ mass spectrophotometer according to method reported elsewhere [43]. The changein toxicity of the treated SMT solution was studied by measuring the inhibition of the bio-luminescence of the bacteria Allivibrio fischeri formerly known as Vibrio fischeri using Microtox ${ }^{\circledR}$ method. The $\mathrm{pH}$ of all the samples and blank was adjusted to $6.5-7.5$ with the aid of $0.01-0.1 \mathrm{mM} \mathrm{NaOH}$ solution prior to Microtox analysis as described elsewhere [44].

\section{Results and discussions}

\subsection{Electrode preparation}

The $\mathrm{Fe}^{\mathrm{II}} \mathrm{Fe}^{\mathrm{III}} \mathrm{LDH}$ modified CF electrode was made by on-site solvothermal synthesis $[14,40]$ using urea and ammonium fluoride as precipitation agent. Multiwall of $\mathrm{Fe}^{\mathrm{II}} \mathrm{Fe}^{\mathrm{III}} \mathrm{LDH}$ was deposited on $\mathrm{CF}$ during hydrothermal treatment at $100{ }^{\circ} \mathrm{C}$. During the hydrothermal treatment, there is gradual decomposition of $\mathrm{CO}\left(\mathrm{NH}_{2}\right)_{2}$ (eq. 6) and hydrolysis of $\mathrm{NH}_{4} \mathrm{~F}$ (eq. 7) which gradually increases the $\mathrm{pH}$ of the solution towards basic $\mathrm{pH}$, thus inducing simultaneous nucleation, crystallization and growth of the metallic hydroxides on the CF substrate [14]. The reactions at the hydrothermal temperature are given in eq. $6-8$ :

$$
\begin{aligned}
& \mathrm{CO}\left(\mathrm{NH}_{2}\right)_{2}(\mathrm{aq})+3 \mathrm{H}_{2} \mathrm{O}_{(\mathrm{l})}+\Delta \text { heat } \rightarrow 2 \mathrm{NH}_{4}{ }_{(\text {aq })}+2 \mathrm{OH}^{-}{ }_{(\mathrm{aq})}+\mathrm{CO}_{2(\mathrm{~g})} \\
& \mathrm{NH}_{4} \mathrm{~F}_{(\mathrm{aq})}+\mathrm{H}_{2} \mathrm{O}_{(\mathrm{l})} \rightarrow \mathrm{NH}_{4}^{+}{ }_{(\text {aq })}+\mathrm{OH}^{-}{ }_{(\mathrm{aq})}+\mathrm{HF}_{(\mathrm{aq})} \\
& \mathrm{Fe}^{2+}{ }_{\text {(aq) }}+\mathrm{Fe}^{3+}{ }_{(\mathrm{aq})}+\mathrm{OH}^{-}{ }_{\text {(aq })} \rightarrow \mathrm{Fe}^{\mathrm{II}} \mathrm{Fe}^{\mathrm{III}} \mathrm{LDH}_{(\mathrm{s})}
\end{aligned}
$$


The nucleation and growth of the LDH occurs majorly at the surface and within the CF immersed in the growth solution and the wall of the Teflon because both are high energy regions compared to the bulk of the solution [14].

\section{2 electrode characterization}

The morphology of the raw and prepared modified cathode analyzed by SEM is shown in Fig. 1. The pretreated raw CF was cleaned and free from dirt as shown in Fig. 1a and $1 \mathrm{~b}$. Bysimple hydrothermal approach in $\mathrm{Fe}^{2+}$ and $\mathrm{Fe}^{3+}$ growth solution, extensive growth of dense platelets of $\mathrm{Fe}^{\mathrm{II}} \mathrm{Fe}^{\mathrm{III}} \mathrm{LDH}$ covered each strands of the CF (Fig. 1c). A magnified image of Fig. 1c shows a rough, uneven and porous structure with more secondary phase precipitated along with the $\mathrm{Fe}^{\mathrm{II}} \mathrm{Fe}^{\mathrm{III}} \mathrm{LDH}$ (Fig. 1d) [45].
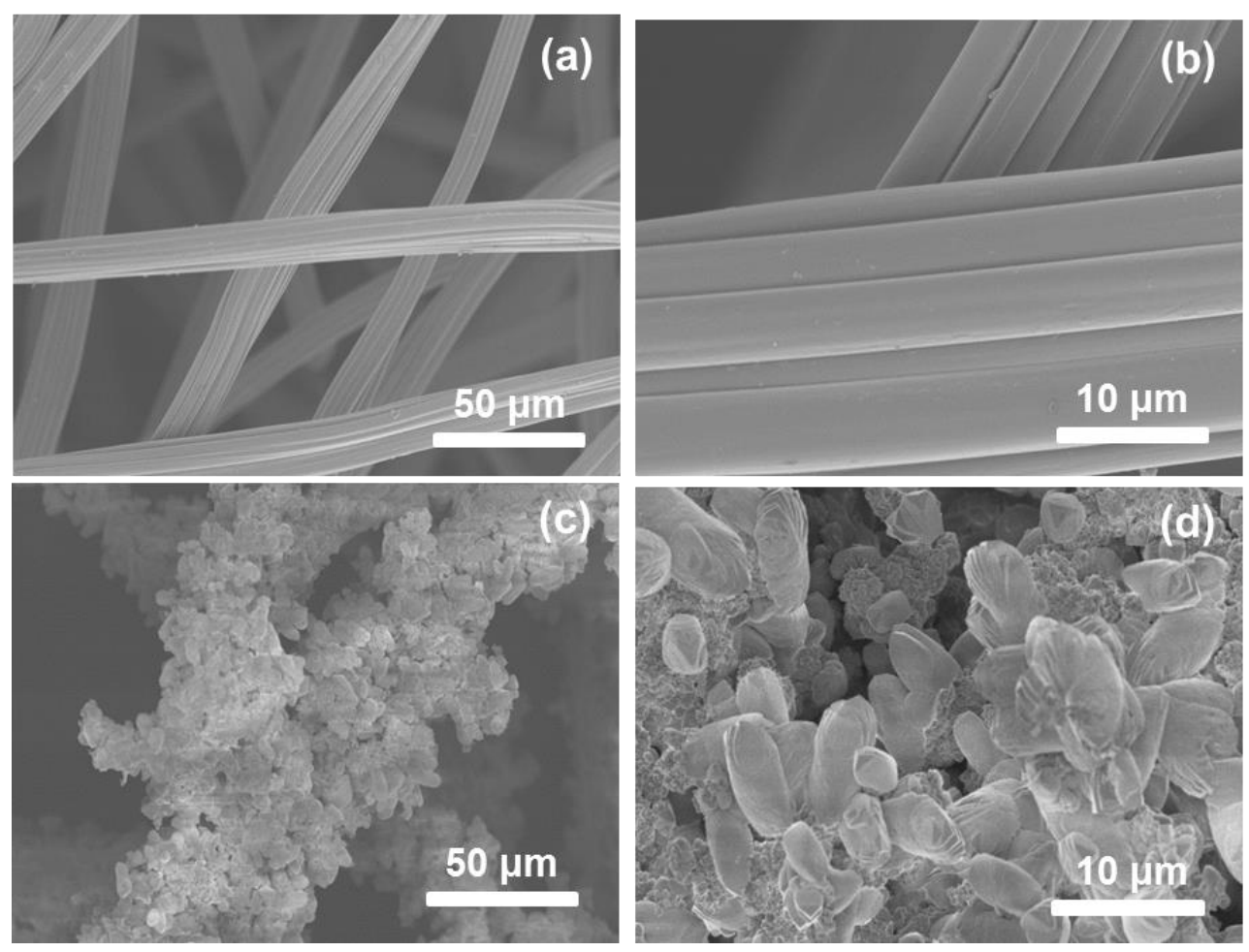

Figure 1: SEM images of (a,b) pretreated raw $\mathrm{CF}$, and (c,d) $\mathrm{Fe}^{\mathrm{II}} \mathrm{Fe}^{\mathrm{III}} \mathrm{LDH} / \mathrm{CF}$ 
Crystallinity of the prepared LDH modified CF as well as LDH powder were examined by XRD and showed in Fig. 2a. The XRD patterns of the powders and the modified CF indicated characteristics peaks corresponding to crystal planes of a typical hydrotalcite-like phase [46]. The diffraction peaks $\left(2 \theta=6^{\circ}, 12^{\circ}, 18^{\circ}, 23^{\circ}\right.$ and $\left.33^{\circ}\right)$ in Fig. 2a represent a typical layered structure with the peaks corresponding to O0lplane of hydrotalcite-like phase, along with extensive growth of the crystal as depicted by the peaks between $2 \theta$ of $30^{\circ}$ and $55^{\circ}$. $\mathrm{TheFe}^{\mathrm{II}} \mathrm{Fe}^{\mathrm{III}}$ LDH crystal showed a good symmetry as depicted by couple of peaks at $57^{\circ}$ and $59^{\circ} 2 \theta$ (Fig. 2a). Additionally, the presence of some secondary phases in $\mathrm{Fe}^{\mathrm{II}} \mathrm{Fe}^{\mathrm{III}} \mathrm{LDH}$ was shown by the diffraction peaks at $22^{\circ}, 31^{\circ}, 36^{\circ}$ and $62^{\circ} 2 \theta$, corresponding to $\mathrm{Fe}(\mathrm{OH})_{3}, \mathrm{Fe}_{2} \mathrm{O}_{3}$, maghemite $\mathrm{Fe}_{2} \mathrm{O}_{3}$ and transformation between $\mathrm{Fe}(\mathrm{OH})_{3}$ and $\mathrm{Fe}_{2} \mathrm{O}_{3}$ respectively [46,47], which is in agreement with the SEM images (Fig. 1d). The peaks around $23^{\circ}$ and $43^{\circ}$ in lower diffractogram of Fig. 2aare ascribed to the carbon of the CF. Besides, low intensity peaks was observed with LDH modified CF compared to that of LDH powder.

The FTIR spectrum of the Fe ${ }^{\mathrm{II}} \mathrm{Fe}^{\mathrm{III}} \mathrm{LDH}$ powder (Fig. 2b) shows two absorption bands at $3750 \mathrm{~cm}^{-1}$ and $3700 \mathrm{~cm}^{-1}$ assigned to stretching vibration of non-hydrogen and hydrogen bond hydroxyl groups in the octahedral sheet and interlayer of the $\mathrm{Fe}^{\mathrm{II}} \mathrm{Fe}^{\mathrm{III}} \mathrm{LDH}$. The peak observed at $1650 \mathrm{~cm}^{-1}$ was ascribedto the bending vibration of absorbed water molecule onto the $\mathrm{Fe}^{\mathrm{II}} \mathrm{Fe}^{\mathrm{III}}$ LDH. An intense peak at $1379 \mathrm{~cm}^{-1}$ was due to the $\mathrm{N}-\mathrm{O}$ stretching mode of the surface adsorbed nitrate counter anions, which were incorporated primarily from $\mathrm{Fe}\left(\mathrm{NO}_{3}\right)_{3} .9 \mathrm{H}_{2} \mathrm{O}$ of the starting solution [45]. Besides, the bands between $580-800 \mathrm{~cm}^{-1}$ wavelength could be ascribed to stretching vibration of $\mathrm{M}-\mathrm{OH}$ and $\mathrm{M}-\mathrm{O}$ bonds $(\mathrm{M}=\mathrm{Fe})$ in the $\mathrm{LDH}$ [48]. 

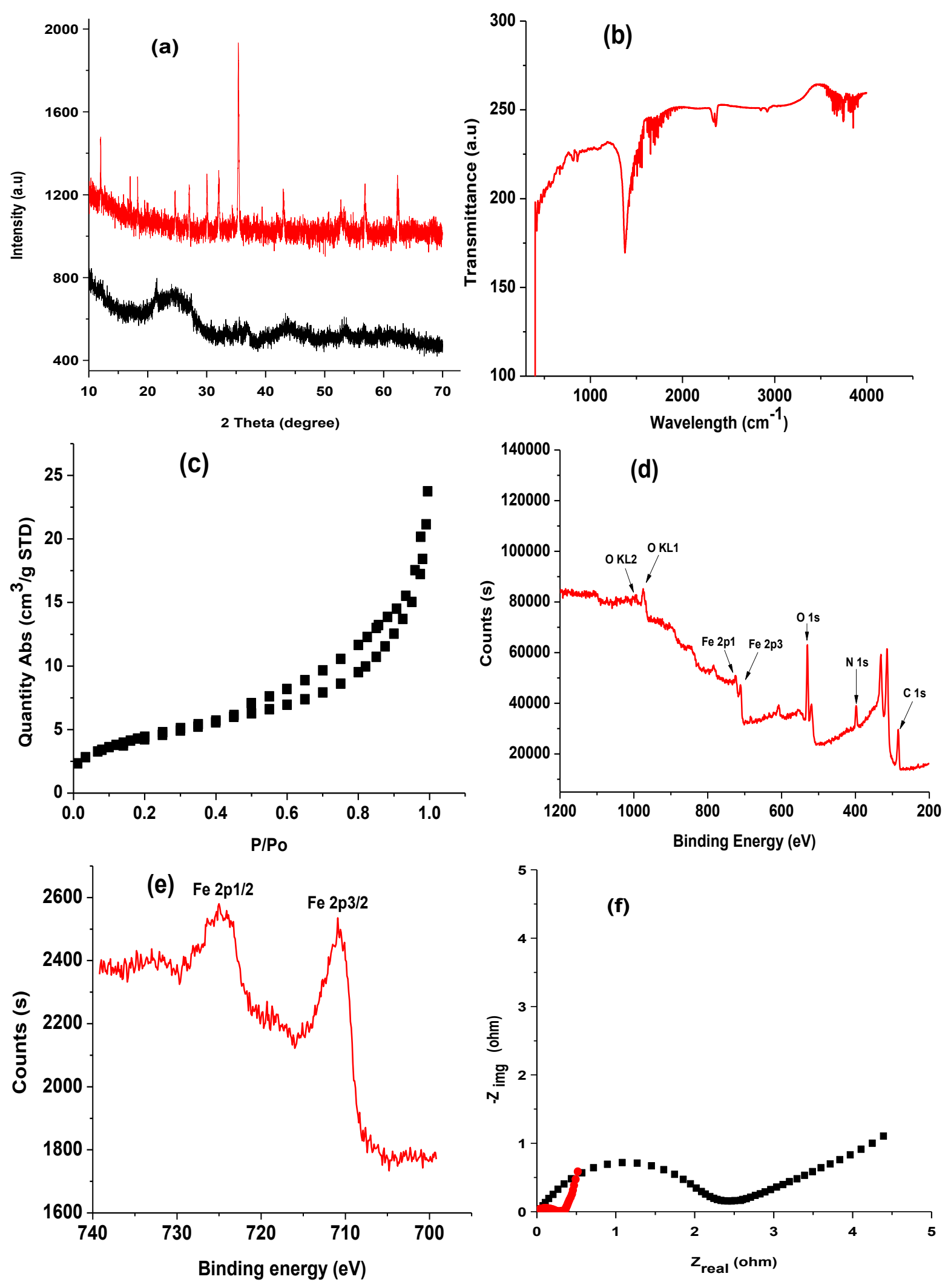
Figure 2: X-ray diffraction patterns of (a) $\mathrm{Fe}^{\mathrm{II}} \mathrm{Fe}^{\mathrm{III}} \mathrm{LDH}$ powder (upper diffractogram) and $\mathrm{Fe}^{\mathrm{II}} \mathrm{Fe}^{\mathrm{III}} \mathrm{LDH} / \mathrm{CF}$ (lower diffractogram), (b) FTIR spectrum of $\mathrm{Fe}^{\mathrm{II}} \mathrm{Fe}^{\mathrm{III}} \mathrm{LDH}$ powder, (c) $\mathrm{N}_{2}$ adsorption isotherm of $\mathrm{Fe}^{\mathrm{II}} \mathrm{Fe}^{\mathrm{III}} \mathrm{LDH}$ powder and, (d) XPS core level spectra of $\mathrm{Fe}^{\mathrm{II}} \mathrm{Fe}^{\mathrm{III}}$ $\mathrm{LDH} / \mathrm{CF}$, (e)XPS spectra of $\mathrm{Fe} 2 \mathrm{p}$ of $\mathrm{Fe}^{\mathrm{II}} \mathrm{Fe}^{\mathrm{III}} \mathrm{LDH} / \mathrm{CF}$ and (f) EIS spectra of ( $\boldsymbol{\varpi}$ ) raw $\mathrm{CF}$ and $(\bullet) \mathrm{Fe}^{\mathrm{II}} \mathrm{Fe}^{\mathrm{III}} \mathrm{LDH} / \mathrm{CF}$ obtained at $10 \mathrm{mV}$ and $50 \mathrm{kHz}-100 \mathrm{MHz}$.

The $\mathrm{N}_{2}$ adsorption isotherm of the $\mathrm{Fe}^{\mathrm{II}} \mathrm{Fe}{ }^{\mathrm{III}} \mathrm{LDH}$ powder is shown in Fig. 2c, exhibiting type IV isotherm with regular pores as demonstrated by the adsorption-desorption plot. Additionally, the BET surface area of the $\mathrm{Fe}^{\mathrm{II}} \mathrm{Fe}^{\mathrm{III}} \mathrm{LDH}$ powder was $16.5 \mathrm{~m}^{2} \mathrm{~g}^{-1}$. The XPS spectra of the $\mathrm{Fe}^{\mathrm{II}} \mathrm{Fe}^{\mathrm{III}} \mathrm{LDH} / \mathrm{CF}$ is shown in Fig. 2d and 2e. The XPS core level spectra (2d)) showed the existential state of elements like oxygen (KL and 1s), Fe (2p1/2 and 2p3/2), N (1s) as well as C (1s) indicating successful modification of CF. More so, the Fe 2p core lines split into 2p1/2 (725 eV) and 2p3/2 (711 eV) peaks (Fig. 2e) with the both peaks accompanied by a small satellite band at around $732 \mathrm{eV}$ and 720 respectively [14].The electrical conductivity and potential of electron transfer capacity of the synthesized $\mathrm{Fe}^{\mathrm{II}} \mathrm{Fe}^{\mathrm{III}} \mathrm{LDH}$ modified $\mathrm{CF}$ as well as raw $\mathrm{CF}$ was examined by EIS and presented in Fig. 2f. The interfacial charge-transfer resistance $\left(\mathrm{Rc}_{\mathrm{t}}\right)$ was presented as suppressed semicircle arcs by the Nyquist plots with the diameter of the semicircle represent the actual value of the $\mathrm{Rc}_{\mathrm{t}}$. It is obvious from Fig. $2 \mathrm{f}$ that there was tremendous decrease in the interfacial resistance after the deposition of the $\mathrm{Fe}^{\mathrm{II}} \mathrm{Fe}^{\mathrm{III}} \mathrm{LDH}$, indicating significant enhancement in electron transfer and electrical conductivity of the electrode. This could enhance the activity of the prepared cathode in terms of $\mathrm{H}_{2} \mathrm{O}_{2}$ production as well as $\mathrm{Fe}^{\mathrm{II}} / \mathrm{Fe}^{\mathrm{III}}$ or $\mathrm{Fe}^{3+} / \mathrm{Fe}^{2+}$ redox regeneration [49]. 


\subsection{Mineralization and degradation of SMT: Effect of $\mathrm{pH}$ and cathode}

The catalytic activity of the as-prepared $\mathrm{Fe}^{\mathrm{II}} \mathrm{Fe}^{\mathrm{III}}$ modified $\mathrm{CF}$ cathode for the efficient electrochemical wastewater treatment over a wide $\mathrm{pH}$ range $(\mathrm{pH} 3-9)$ was investigated by studying the degradation and mineralization of the antibiotic SMT as a model pollutant. It is worthy to state that the $\mathrm{LDH} / \mathrm{CF}$ as well as the pretreated raw $\mathrm{CF}$ showed limited or no adsorption of the SMT with less than $1 \%$ TOC abatement after $8 \mathrm{~h}$ in control experiment. HEF treatment with $\mathrm{Fe}^{\mathrm{II}} \mathrm{Fe}^{\mathrm{III}} \mathrm{LDH} / \mathrm{CF}$ cathode showed almost complete mineralization of SMT solutions over the $\mathrm{pH}$ range studied at applied current density of $7.5 \mathrm{~mA} \mathrm{~cm}{ }^{-2}$ (Fig. 3a). In fact the initial $\mathrm{pH}$ of the treated solution has limited influence on the mineralization of SMT solutions during the HEF treatment. For instance, mineralization efficiency of $97 \%, 93 \%$ and $90 \%$ was achieved during $\mathrm{HEF}$ treatment with $\mathrm{Fe}^{\mathrm{II}} \mathrm{Fe}^{\mathrm{III}} \mathrm{LDH} / \mathrm{CF}$ at $\mathrm{pH} 3,6$ and 9 respectively after $8 \mathrm{~h}$ of electrolysis, demonstrating the higher efficiency of this process compared to either $\mathrm{EO}-\mathrm{H}_{2} \mathrm{O}_{2}$ and EF-Fe ${ }^{2+}$ at all pH studied (Fig. 4). The excellent mineralization of SMT achieved with $\mathrm{Fe}^{\mathrm{II}} \mathrm{Fe}^{\mathrm{III}}$ $\mathrm{LDH} / \mathrm{CF}$ at both acidic and basic $\mathrm{pH}$ can be attributed to surface catalyzed decomposition of $\mathrm{H}_{2} \mathrm{O}_{2}$ to produced ${ }^{\bullet} \mathrm{OH}$ which can easily oxidized SMT and its oxidation intermediates[13,18]. The surface catalyzed process widening the $\mathrm{pH}$ window at which HEF can be carried out without necessarily reduced the efficiency of the process because the reaction occurs at solid-liquid interface in the treated solution. As shown in Figs. $3 \mathrm{a}$ and 4, less than $10 \%$ reduction in TOC removal efficiency was observed when the $\mathrm{pH}$ of the treated solution was increased from $\mathrm{pH} 3$ to $\mathrm{pH}$ 9. Besides, the surface catalyzed process eliminates the formation of iron hydroxide sludge encountered in homogeneous EF since there was limited leaching of Fe from LDH at basic $\mathrm{pH}$ and the solution treated with LDH modified CF remained clear regardless of the initial solution 
$\mathrm{pH}$. It is important to state that at acidic $\mathrm{pH}$ (i.e. $\mathrm{pH} 3$ ), the oxidation of SMT was by both surface catalyzed process at the surface of the modified cathode and $\mathrm{EF}-\mathrm{Fe}^{2+}$ oxidation arisen from the leaching of $\mathrm{Fe}^{3+} / \mathrm{Fe}^{2+}$ from the $\mathrm{LDH}$ into the treated solution, in addition to $\mathrm{Ti}_{4} \mathrm{O}_{7}\left({ }^{\bullet} \mathrm{OH}\right)$ generated at the anode surface via water oxidation reaction (eq. 4). The leached $\mathrm{Fe}^{3+} / \mathrm{Fe}^{2+}$ can catalyzed the decomposition of $\mathrm{H}_{2} \mathrm{O}_{2}$ to produce ${ }^{\bullet} \mathrm{OH}$ in Fenton's reaction (eq. 1). The leaching of $\mathrm{Fe}$ ions species from the $\mathrm{LDH}$ and the quantity leached was confirmed and estimated by colorimetric method and detailed in section 3.3.
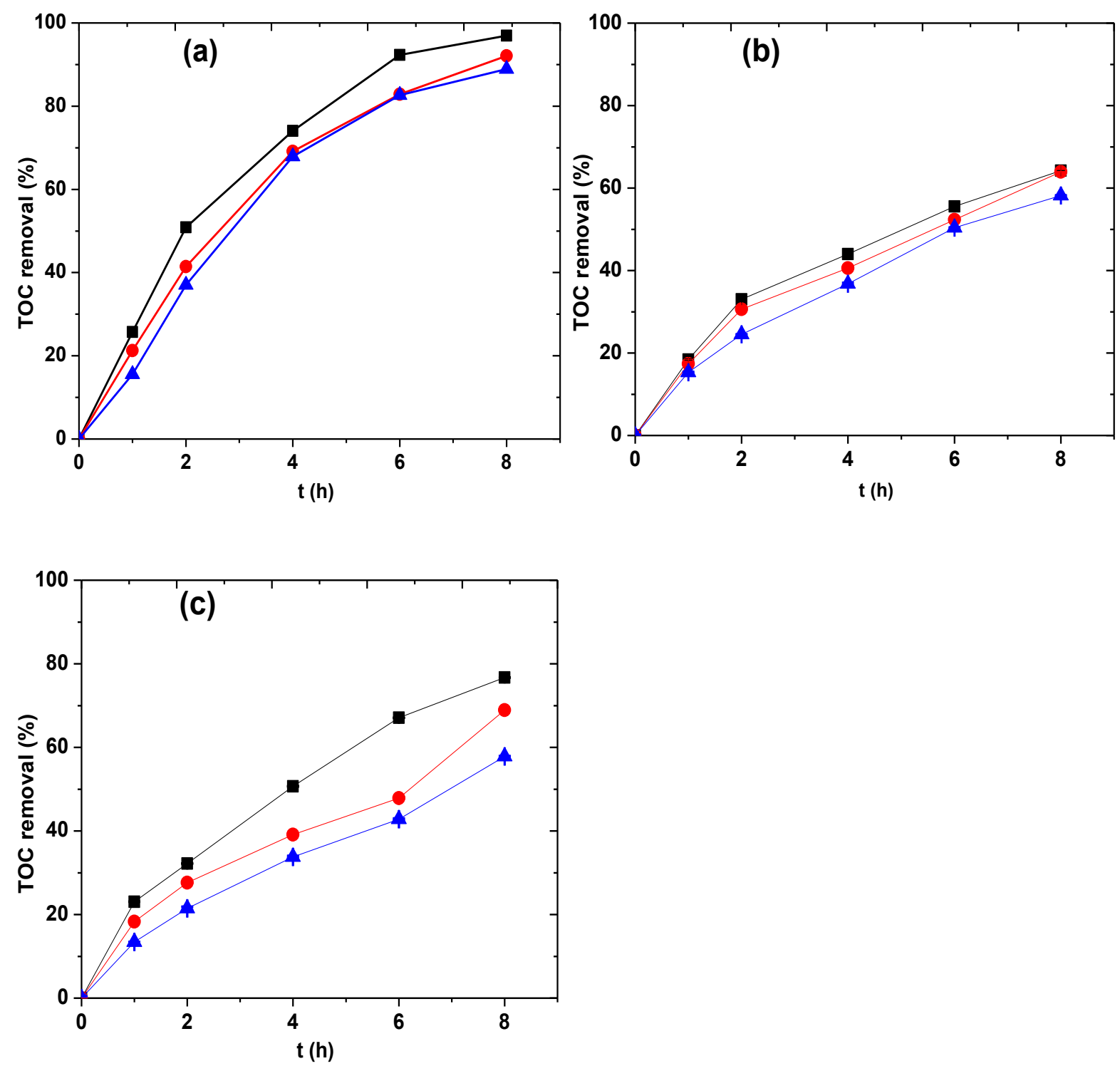
Figure 3: TOC removal efficiency $v s$ time during the mineralization of $24 \mathrm{mg} \mathrm{L}^{-1}$ TOC SMT solution at: $(\boldsymbol{\bullet}) \mathrm{pH} \mathrm{3,( \bullet )} \mathrm{pH} 6$ and $(\boldsymbol{\Delta}) \mathrm{pH} 9$ and current density of $7.5 \mathrm{~mA} \mathrm{~cm}^{-2}$ using (a) HEF with $\mathrm{Fe}^{\mathrm{II}} \mathrm{Fe}^{\mathrm{III}} \mathrm{LDH} / \mathrm{CF}$ cathode, (b) EO- $\mathrm{H}_{2} \mathrm{O}_{2}$ and (c)EF-Fe ${ }^{2+}(\mathrm{RSD}:<2 \%)$. Anode: $\mathrm{Ti}_{4} \mathrm{O}_{7}$

Comparatively, the mineralization of SMT studied with zero catalyst addition (i.e. EO$\mathrm{H}_{2} \mathrm{O}_{2}$ ) using pretreated raw $\mathrm{CF}$ as cathode and $\mathrm{Ti}_{4} \mathrm{O}_{7}$ anode showedmoderate TOC removal efficiency (Fig. 3b) at all pH studied, achieving 64\%, 63\% and 53\% TOC removal at pH 3, 6 and 9 respectively after $8 \mathrm{~h}$ of electrolysis. This clearly shows that the modification of the cathode contributed more than $30 \%$ of the mineralization achieved in HEF process. The mineralization of SMT in this case was mainly by physisorbed $\mathrm{Ti}_{4} \mathrm{O}_{7}\left({ }^{\bullet} \mathrm{OH}\right)$ generated at the surface of the $\mathrm{Ti}_{4} \mathrm{O}_{7}$ anode since no catalyst was added to the treated solutions, as such no ${ }^{\bullet} \mathrm{OH}$ production in the bulk solution $[43,50,51]$. Upon addition of optimized catalytic quantity of iron $\left(0.2 \mathrm{mM} \mathrm{Fe}{ }^{2+}\right)[30,50]$ to the treated solutions (i.e. $\mathrm{EF}-\mathrm{Fe}^{2+}$ ), an enhanced mineralization of SMT solution was achieved with TOC removal efficiency of 77\%, 69\% and 58\% achieved at pH 3, 6 and 9 respectively (Fig. 3c). This enhanced mineralization of SMT was expected because of the contribution of homogeneously generated $\bullet \mathrm{OH}$ from Fenton's reaction (eq. 1) between electrogenerated $\mathrm{H}_{2} \mathrm{O}_{2}$ produced at the cathode and catalytic $\mathrm{Fe}^{2+}$ added to the solution prior to treatment $[52,53]$. The TOC removal efficiency during classical EF treatment was significantly reduced with increase in $\mathrm{pH}$ majorly due to the precipitation of the $\mathrm{Fe}^{2+}$ as hydroxides. In fact, the treated solutions at $\mathrm{pH}$ 6 and 9 remained yellow throughout electrolysis time, indicating the continuous presence of iron hydroxides in the solution; and the mineralization attained at these pHs was majorly by $\mathrm{Ti}_{4} \mathrm{O}_{7}\left({ }^{\bullet} \mathrm{OH}\right)$ generated at the surface of the anode. In all cases, the mineralization efficiency obtained with $\mathrm{Fe}^{\mathrm{II}} \mathrm{Fe}^{\mathrm{III}} \mathrm{LDH} / \mathrm{CF}$ was always higher at all electrolysis time and $\mathrm{pH}$ values 
compared to $\mathrm{EO}-\mathrm{H}_{2} \mathrm{O}_{2}$ or $\mathrm{EF}^{-\mathrm{Fe}^{2+}}$ as depicted in Fig. 4. More so, the HEF with $\mathrm{Fe}^{\mathrm{II}} \mathrm{Fe}^{\mathrm{III}} \mathrm{LDH} / \mathrm{CF}$ could be an interesting technique for treatment of industrial effluents, especially those from

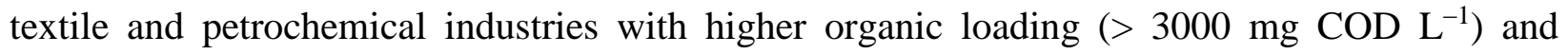
varying $\mathrm{pH}[5]$ since the efficiency of the process was marginally affect by $\mathrm{pH}$.

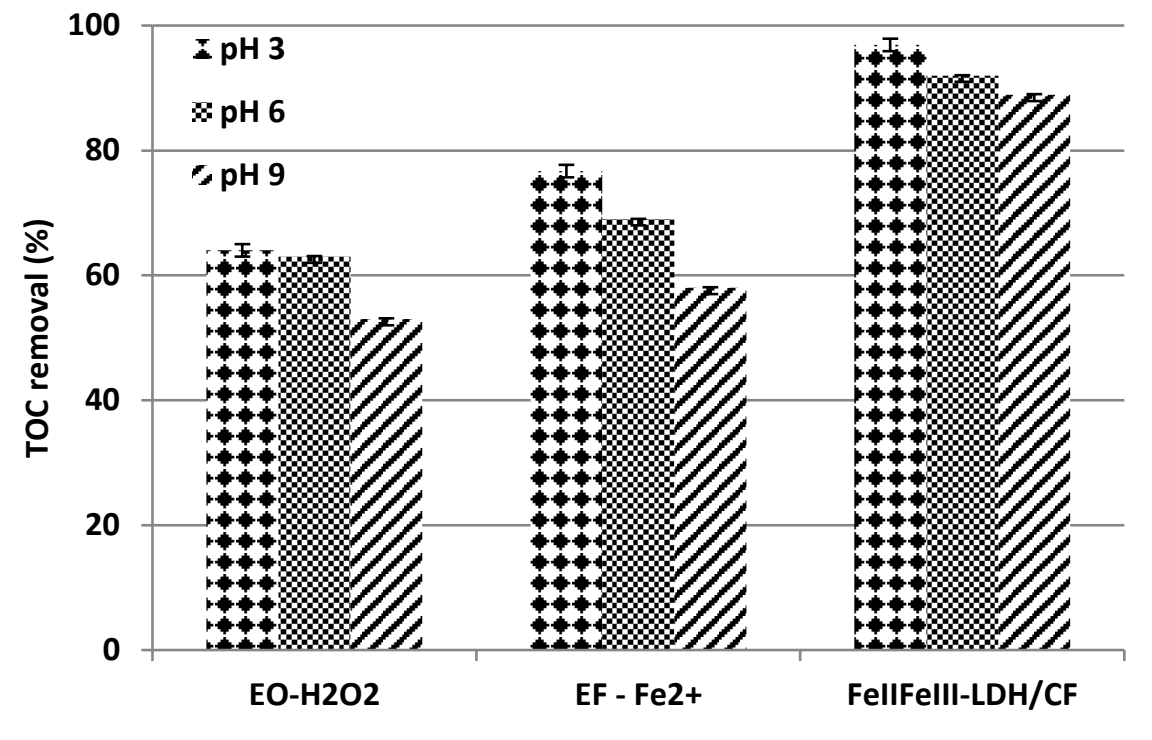

Figure 4: Comparison of the mineralization efficiency at different $\mathrm{pHs}$ for the treatment of 24

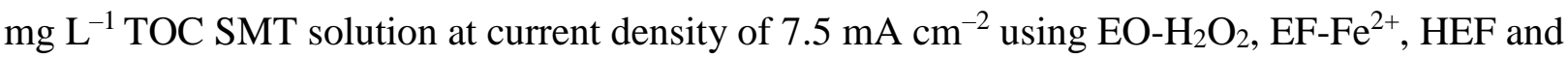
$\mathrm{Fe}^{\mathrm{II}} \mathrm{Fe}^{\mathrm{III}} \mathrm{LDH} / \mathrm{CF}$ after $8 \mathrm{~h}$ of electrolysis. Anode $\mathrm{Ti}_{4} \mathrm{O}_{7}$

Fig. 5 showed the corresponding SMT concentration decay with electrolysis time for all the trials of Fig. 3. Complete degradation of SMT was attained in all trials with time required for completeoxidation of SMT increases with $\mathrm{pH}$ for all the processes studied. As can be seen in Fig. 5, excellent degradation efficiency was obtained during $\mathrm{HEF}$ process with $\mathrm{Fe}^{\mathrm{II}} \mathrm{Fe}^{\mathrm{III}} / \mathrm{CF}$ compared to $\mathrm{EO}-\mathrm{H}_{2} \mathrm{O}_{2}$ and $\mathrm{EF}-\mathrm{Fe}^{2+}$ at analogous experimental conditions. For example, complete degradation of $0.2 \mathrm{mM}$ SMT solution was achieved after 40, 120 and 240 min at $\mathrm{pH} \mathrm{3,6}$ and 9 
respectively, during $\mathrm{HEF}$ with $\mathrm{Fe}^{\mathrm{II}} \mathrm{Fe}^{\mathrm{III}} / \mathrm{CF}$, whereas it requires over 120, 240 and 360 min; and 60, 240 and 360 min to obtained complete destruction of SMT with EO- $\mathrm{H}_{2} \mathrm{O}_{2}$ and $\mathrm{EF}-\mathrm{Fe}^{2+}$ at $\mathrm{pH}$ 3, 6 and 9 respectively. The much slower degradation rate observed during $\mathrm{EO}-\mathrm{H}_{2} \mathrm{O}_{2}$ (without $\mathrm{Fe}^{2+}$ ) (Fig.5b) compared to EF-Fe ${ }^{2+}$ or $\mathrm{HEF}$ can be explained by the fact that the $\mathrm{Ti}_{4} \mathrm{O}_{7}\left({ }^{\bullet} \mathrm{OH}\right)$ are produced and confined to the anode region only, thus oxidation of SMT was mainly diffusion controlled [54]. Besides, at higher $\mathrm{pH}(\mathrm{pH} 6$ and 9) slower degradation was observed with EF$\mathrm{Fe}^{2+}$ (Fig. 5c), which could be explained by the precipitation of the $\mathrm{Fe}^{2+}$ (catalyst) as ferric hydroxide from the solution, reducing the catalytic generation of $\bullet$ OH via Fenton's reaction. Indeed, both the degradation and mineralization of SMT solution at these pHs were predominantly by $\mathrm{Ti}_{4} \mathrm{O}_{7}\left({ }^{\bullet} \mathrm{OH}\right)$ generated at the anode via water oxidation.
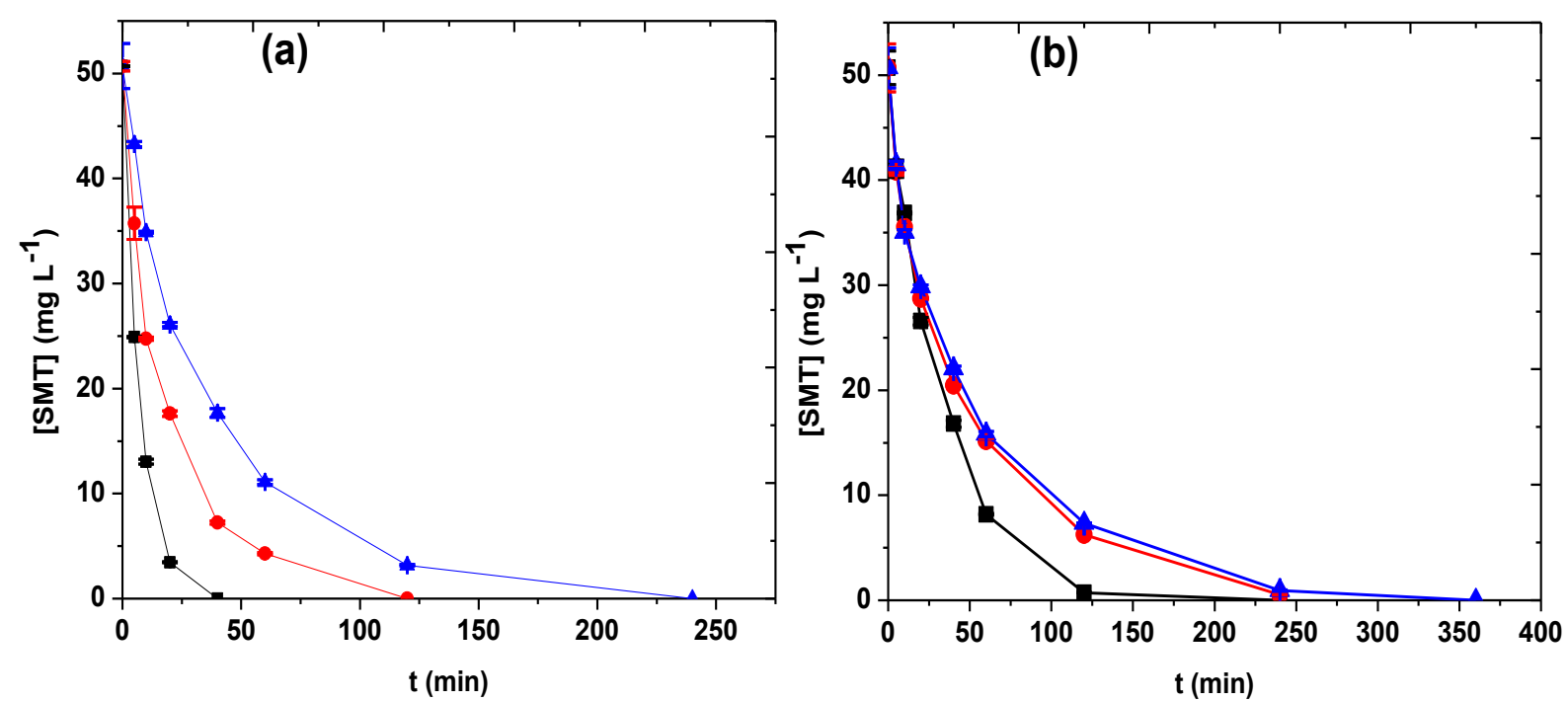


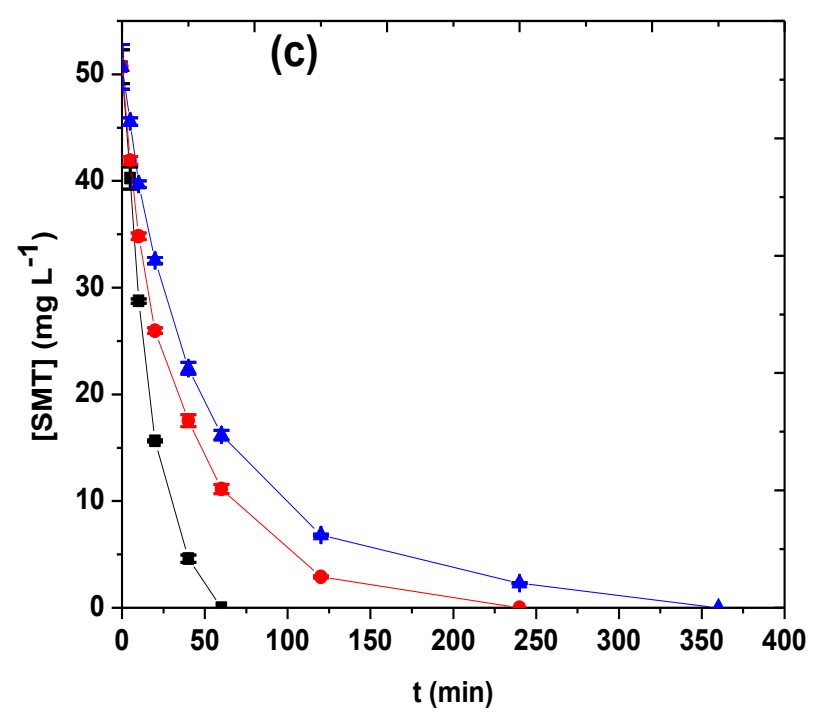

Figure 5: Concentration decay $v s$ electrolysis time during the degradation of $50.7 \mathrm{mg} \mathrm{L}^{-1}(0.2$ $\mathrm{mM}$ ) SMT at: (•) pH $3(\bullet) \mathrm{pH} 6$ and $(\boldsymbol{\Delta}) \mathrm{pH} 9$ and current density of $7.5 \mathrm{~mA} \mathrm{~cm}^{-2}$ using (a) HEF with $\mathrm{Fe}^{\mathrm{II}} \mathrm{Fe}{ }^{\mathrm{III}} \mathrm{LDH} / \mathrm{CF}$ cathode, (b) $\mathrm{EO}-\mathrm{H}_{2} \mathrm{O}_{2}$ and (c) $\mathrm{EF}-\mathrm{Fe}^{2+}$. Anode: $\mathrm{Ti}_{4} \mathrm{O}_{7}$

\subsection{Evolution of $\mathrm{pH}$ and Feleaching during electrolysis}

The initial $\mathrm{pH}$ of the wastewater and its evolution during electrochemical treatment based on Fenton's chemistry has a significant role on the efficiency of the process because the $\mathrm{pH}$ affects the availability of the $\mathrm{Fe}^{3+} / \mathrm{Fe}^{2+}$ cycles (Fenton catalyst) in the solution. Indeed, $\mathrm{Fe}^{3+} / \mathrm{Fe}^{2+}$ andother heavy metals precipitate as hydroxides as $\mathrm{pH}$ increases towards basic $\mathrm{pH}$ values. Additionally, the stability of $\mathrm{Fe}^{\mathrm{II}} \mathrm{Fe}^{\mathrm{III}} \mathrm{LDH}$ used in HEF depends on the $\mathrm{pH}$ of the solution. In general, LDHs are less stable at strong acidic $\mathrm{pH}$ but barely affected at high $\mathrm{pH}$ values [47]. As such the evolution of $\mathrm{pH}$ of the SMT solution during treatment with $\mathrm{Fe}^{\mathrm{II}} \mathrm{Fe}^{\mathrm{III}} \mathrm{LDH} / \mathrm{CF}$ cathode was monitored and reported in Fig. 6a. Firstly, it is important to state that the variation in $\mathrm{pH}$ of the bulk from electrode regions due to formation of $\mathrm{H}^{+}$and $\mathrm{OH}^{-}$at the anode and cathode respectively was minimized because of strong stirring during the electrolysis that ensures 
homogenization at all time. There was sharp reduction in $\mathrm{pH}$ of the treated solution at the early stage of electrolysis when treated SMT solution at initial $\mathrm{pH}$ 9, but the solution $\mathrm{pH}$ remained almost unchanged after $1 \mathrm{~h}$ till the end of the treatment. Similar but gradual reduction in $\mathrm{pH}$ of the treated solution was observed at $\mathrm{pH} 6$, but the $\mathrm{pH}$ kept nearly constant after $2 \mathrm{~h}$ of the treatment. The observed reduction in $\mathrm{pH}$ at the early stage of treatment can be attributed formation of short-chain carboxylic acids from the oxidative degradation of SMT and its cyclic byproducts[2,3,6]. In contrast, the $\mathrm{pH}$ of the treated solution was stable in case of treated SMT solution at pH 3 (Fig. 6a), except for the early slightly increase observed within the first $10 \mathrm{~min}$ of electrolysis which was probably due to the inherited basic condition of preparing the cathode. Note that the change in the $\mathrm{pH}$ of the treated SMT solution over the electrolysis time has negligible effect on the cell potential,with variation of less than $0.4 \mathrm{~V}$ observed for the three $\mathrm{pH}$ values studied (Table 1.)

Table 1: Evolution of cell voltage over electrolysis time during the treatment of SMT solution at different $\mathrm{pH}$ values

\begin{tabular}{|l|l|l|l|l|l|l|l|}
\hline \multicolumn{2}{|l|}{ Time (h) } & 0 & 1 & 2 & 4 & 6 & 8 \\
\hline \multirow{4}{*}{$\mathrm{E}_{\text {cell }}$} & $\mathrm{pH} 3$ & 5.50 & 5.57 & 5.55 & 5.68 & 5.81 & 5.80 \\
\cline { 2 - 8 } & $\mathrm{pH} 6$ & 5.50 & 5.45 & 5.43 & 5.48 & 5.55 & 5.63 \\
\cline { 2 - 8 } & \multirow{2}{*}{$\mathrm{pH} 9$} & 5.47 & 5.53 & 5.43 & 5.46 & 5.57 & 5.64 \\
\hline
\end{tabular}

The quantities of Fe leached from the $\mathrm{Fe}^{\mathrm{II}} \mathrm{Fe}^{\mathrm{III}} \mathrm{LDH} / \mathrm{CF}$ cathode during the treatment of SMT solution at different initial pHs was reported in Fig. 6b. As depicted in Fig 6b, the prepared cathode showed very high stability at high initial SMT solution $\mathrm{pH}$ with the total Fe leached from the cathode less than $1 \mathrm{mg} \mathrm{L}^{-1}$ and $0.5 \mathrm{mg} \mathrm{L}^{-1}$ for the treatment at initial solution $\mathrm{pH}$ value of 6 and 9, respectively. This implied that the contribution of homogeneous $\mathrm{Fe}^{2+} / \mathrm{Fe}^{3+}$ catalyzed 
EF to the degradation of SMT solution was negligible and the mineralization of SMT was predominantly by surface catalyzed process at these $\mathrm{pH}$ values. However, the LDH became slightly unstable at strong acid $\mathrm{pH}$ (i.e. $\mathrm{pH} 3)$ and significant quantities of $\mathrm{Fe}\left(\approx 9 \mathrm{mg} \mathrm{L}^{-1}\right)$ were leached into the treated solution (Fig. 6b), suggesting the participation of EF-Fe ${ }^{2+}$ in the overall mineralization of the SMT solution at $\mathrm{pH}$ 3. The leached Fe existed in the solution as $\mathrm{Fe}^{3+} / \mathrm{Fe}^{2+}$, which can homogeneously catalyzed $\mathrm{H}_{2} \mathrm{O}_{2}$ decomposition to produce ${ }^{\bullet} \mathrm{OH}$. It is important to note that the $\mathrm{Fe}^{3+} / \mathrm{Fe}^{2+}$ redox couple were continuously present in the solution, thanks to the formation of $\mathrm{Fe}^{3+}$ from Fenton's decomposition of $\mathrm{H}_{2} \mathrm{O}_{2}$ by $\mathrm{Fe}^{2+}$ (eq. 1) and cathodic reduction of $\mathrm{Fe}^{3+}$ to $\mathrm{Fe}^{2+}$ (eq. 3).
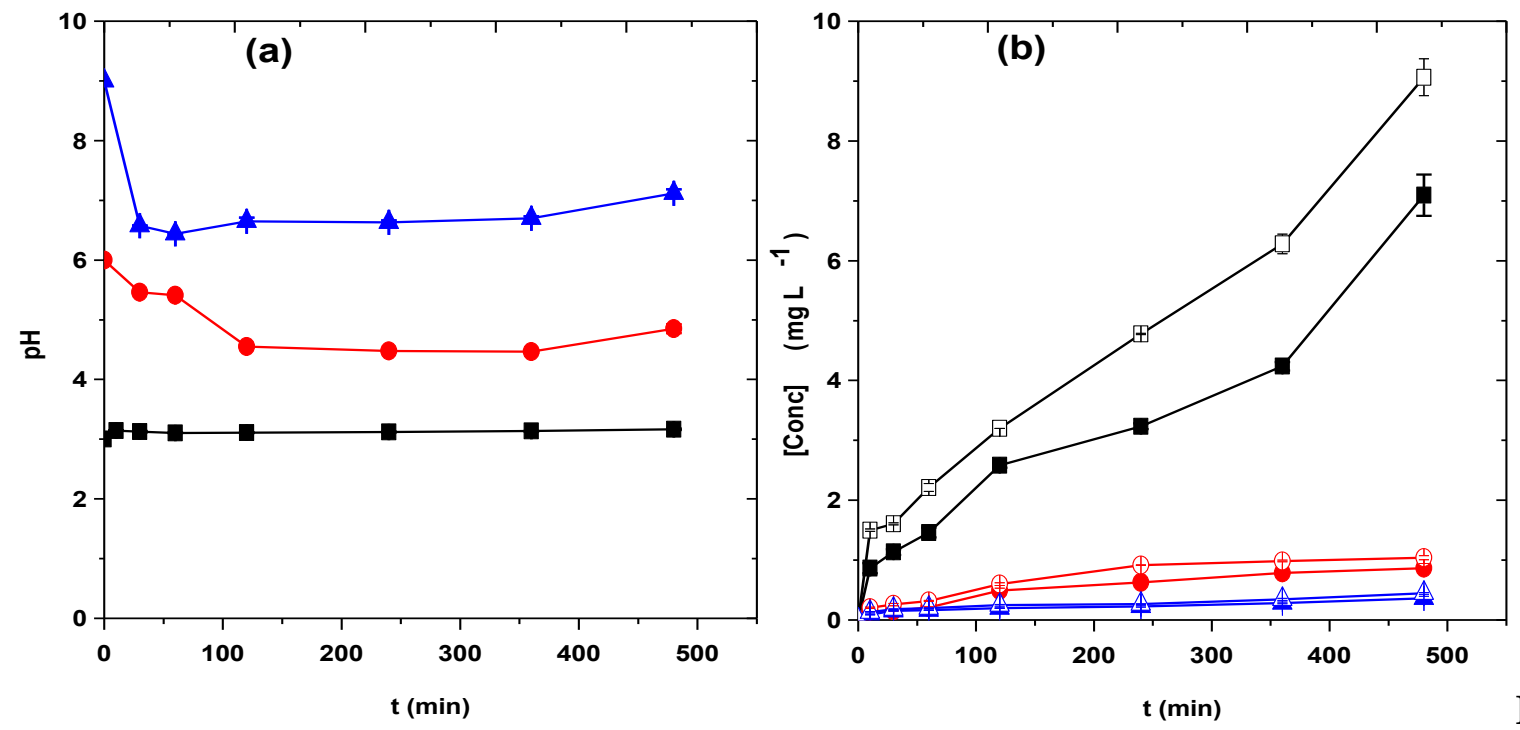

Figure

6: (a) Evolution of $\mathrm{pH}$ with electrolysis time: (•) $\mathrm{pH} 3,(\bullet) \mathrm{pH} 6$ and ( $\boldsymbol{\Delta}$ ) $\mathrm{pH}$ 9; and (b) evolution

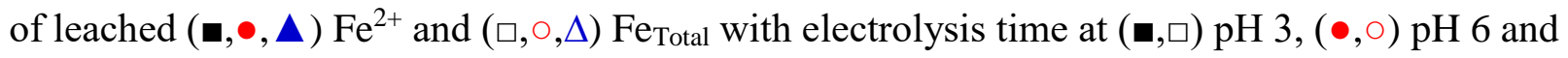
$(\boldsymbol{\Delta}, \Delta) \mathrm{pH} 9$ during the treatment of SMT solution using $\mathrm{Fe}^{\mathrm{II}} \mathrm{Fe}^{\mathrm{III}} \mathrm{LDH} / \mathrm{CF}$ at current density of $7.5 \mathrm{~mA} \mathrm{~cm}^{-2}$. Anode: $\mathrm{Ti}_{4} \mathrm{O}_{7}$ 


\subsection{Evolution of oxidation by-products and reaction pathway}

The mineralization of organic pollutants by hydroxyl radicals generated in electrochemical oxidation generally involves the formation of several cyclic intermediates and release of inorganic ions with the former further oxidized to $\mathrm{C}-4$ carboxylic acids, which are the final end organic by-products in the treated solution [55]. The carboxylic acid generated during the HEF treatment of $0.2 \mathrm{mM} \mathrm{SMT}$ solution at $\mathrm{pH} 6$ and current density of $7.5 \mathrm{~mA} \mathrm{~cm}{ }^{-2}$ using $\mathrm{Fe}^{\mathrm{II}} \mathrm{Fe}^{\mathrm{III}} \mathrm{LDH} / \mathrm{CF}$ cathode was depicted in Fig. 7. Five distinctive peaks were shown on the HPLC chromatograms at $6.8,8.2,10.2,14.3$ and 16.4 min identified to be oxalic, maleic, oxamic, glycoxylic and pyruvic acids. This was confirmed by injecting standard solutions of these acids into reversed phase HPLC using an ion-exclusion column. As shown in Fig. 7, accumulation - destruction cycle was observed for all the carboxylic acids, thanks to the rapid formation from oxidation of SMT and its cyclic intermediate at the early stage and mineralization of the acids with the increase in electrolysis time. Oxalic acid was the most accumulated as expected because it is the final end organic byproducts of oxidation of both cyclic and non-cyclic compound [56,57]. Note that, the carboxylic acids found in the final treated solution accounts for the remnant TOC ( $7 \%$ at $\mathrm{pH} 6)$ reported in Fig. 3. 


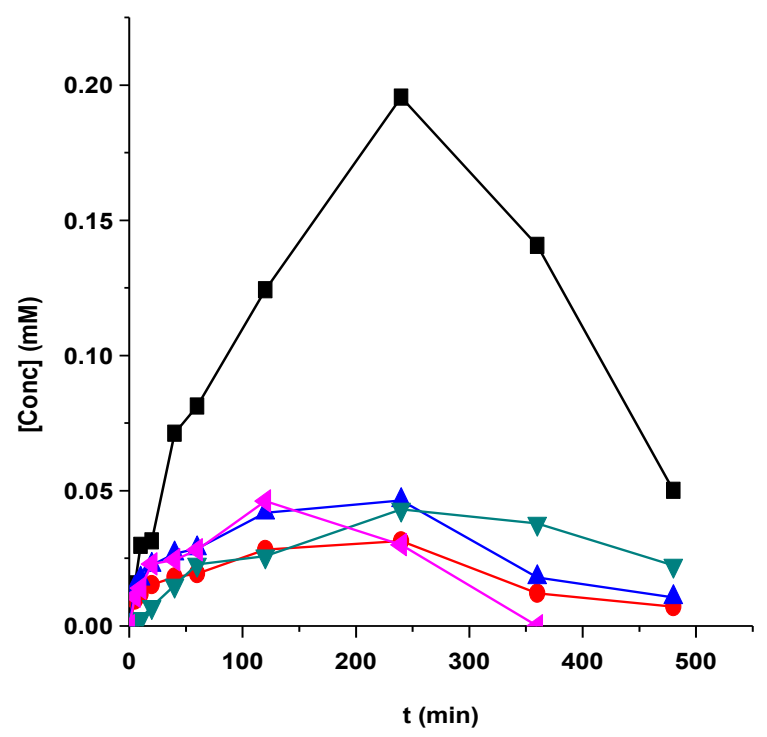

Figure 7: Time course of the main aliphatic carboxylic acids accumulated during HEF treatment of $0.2 \mathrm{mM}$ SMT solution using $\mathrm{Fe}^{\mathrm{II}} \mathrm{Fe}^{\mathrm{III}} \mathrm{LDH} / \mathrm{CF}$ at $\mathrm{pH} 6$ and current density of $7.5 \mathrm{~mA} \mathrm{~cm}{ }^{-2}$.

Acids: $(\boldsymbol{\square})$ oxalic, $(\bullet)$ maleic $(\boldsymbol{\Delta})$ oxamic, $(\boldsymbol{\nabla})$ glycoxylic and $(\varangle)$ pyruvic.

The GC-MS analysis of electrolyzed SMT solution after 30 min showed the formation of several aromatic/cyclic intermediates such as hydroxylated SMT $(\mathrm{m} / \mathrm{z}=267.9)$, 3-amino-5methylisoxazole $(\mathrm{m} / \mathrm{z}=99.09)$, hydroxylated 3-amino-5-methylisoxazole $(\mathrm{m} / \mathrm{z}=116.18)$, 4amino benzene sulfonamide $(\mathrm{m} / \mathrm{z}=175)$, hydroxylated 4 -amino benzene sulfonamide $(\mathrm{m} / \mathrm{z}=$ 191.6), hydroquinone and p-benzoquinone $(\mathrm{m} / \mathrm{z}=110)$. The 3-amino-5-methylisoxazole, hydroxylated SMT, hydroxylated 4-amino benzene sulfonamide, hydroquinone and pbenzoquinone have been identified as aromatic intermediate for SMT oxidation by other studies $[31,32,58]$. Based on these identified cyclic intermediates and the carboxylic acids, a proposed degradation pathway for complete mineralization of SMT by $\mathrm{HEF}$ using $\mathrm{Fe}^{\mathrm{II}} \mathrm{Fe}{ }^{\mathrm{III}} \mathrm{LDH} / \mathrm{CF}$ cathode was given in Fig. 8, assuming hydroxyl radicals as the main oxidant. The degradation of 
SMT molecules was initiated either by the cleavage of the peptide bond to give 3-amino-5methylisoxazole and 4-amino benzene sulfonamide or hydroxylation of SMT to hydroxylated SMT which can further undergoes cleavage of the peptide bond like original SMT molecule. Further hydroxylation, deamination and desulfonation of 4-amino benzene sulfonamide give pbenzoquinone which was further oxidized, along with deaminated 3-amino-5-methylisoxazole to several carboxylic acids that were finally mineralized to $\mathrm{CO}_{2}$ and water. 


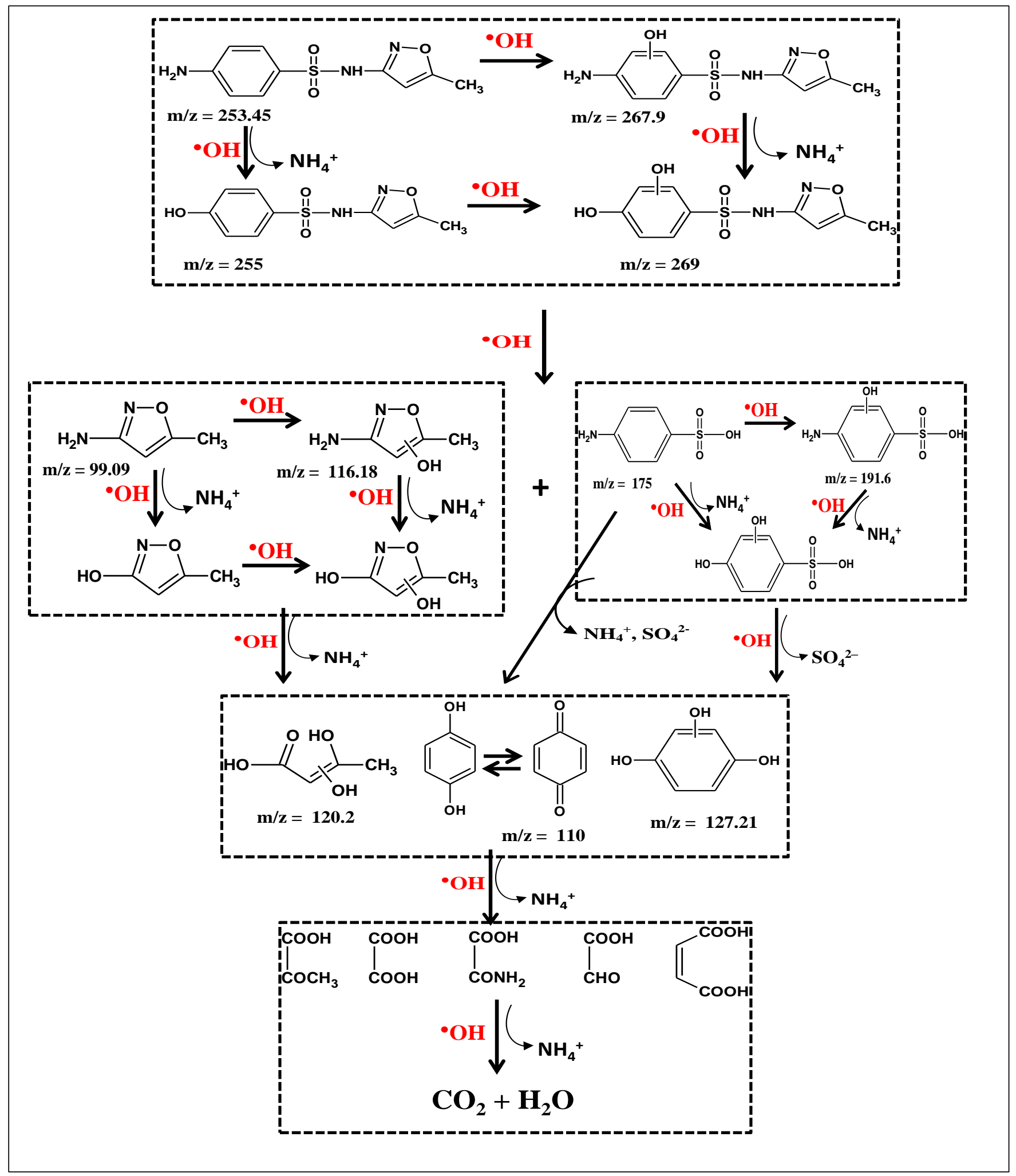


Figure 8: Reaction mechanism for complete degradation of SMT molecule assuming ${ }^{\bullet} \mathrm{OH}$ as the major oxidant.

\subsection{Assessment of toxicity and reusability of $\mathrm{Fe}(\mathrm{II}) \mathrm{Fe}(\mathrm{III}) \mathrm{LDH} / \mathrm{CF}$ cathode}

The evolution of toxicity of SMT solution with electrolysis time during HEF treatment using $\mathrm{Fe}^{\mathrm{II}} \mathrm{Fe}^{\mathrm{III}} \mathrm{LDH} / \mathrm{CF}$ cathode at $\mathrm{pH} 3$ and 6 was assessed by Microtox ${ }^{\circledR}$ method and reported in Figs. 9a and 9b. The initial SMT solution showed relatively high luminescence inhibition to $V$. fischeri bacteria at the beginning of electrolysis, demonstrating the toxicity of the antibiotic. The $\%$ luminescence inhibition quickly increased at the beginning of treatment owing to increased toxicity of the treated solution. Such sharp increase in bacteria inhibition can been attributed to the formation of cyclic byproducts which are more toxic than the parent compounds $[53,59]$. For treatment at $\mathrm{pH} 3$, the high inhibition lasted up to $40 \mathrm{~min}$ of electrolysis before slight reduction and increment to second maximum, indicating the formation of secondary intermediates that are less toxic compared to primary cyclic byproducts. The \% inhibition gradually reduced afterward until almost zero inhibition at the end of the treatment (Fig. 9a), demonstrating the total destruction of SMT, primary and secondary cyclic intermediates into biodegradable byproducts (C-4 carboxylic acids) and detoxification of the solution. Similar trend was observed for treatment at $\mathrm{pH} 6$ (Fig. 9b), however the maximum inhibition of $V$. fischeri bacteria luminescenceof treated solution at the early stage of electrolysislasted for longer time (70 min) compared to what was observed at $\mathrm{pH} 3$ (Fig. 9b), indicating slower degradation of aromatic byproducts at $\mathrm{pH} 6$ in comparisonwith $\mathrm{pH} 3$. This agrees well with the TOC removal efficiency reported in Fig. 3a. 

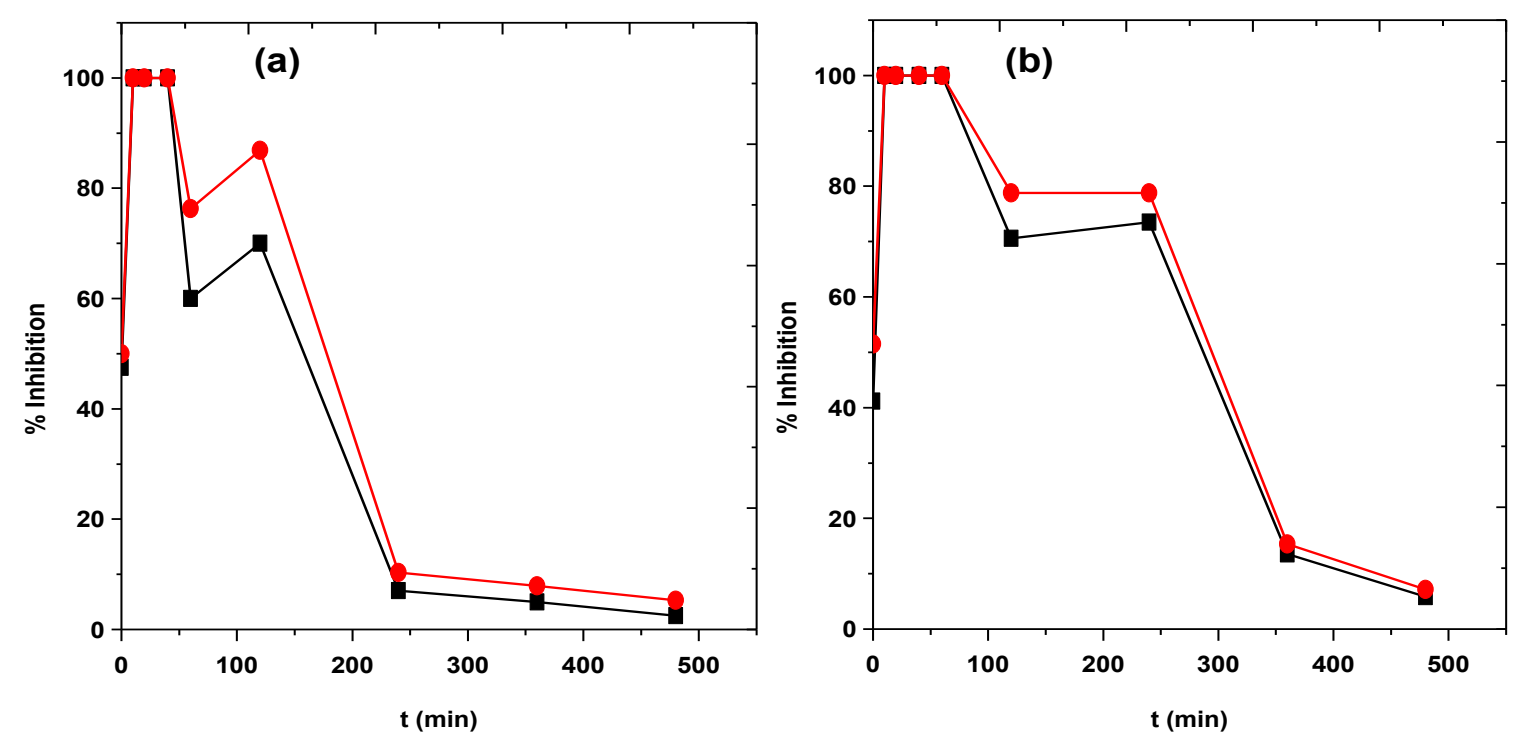

Figure 9:Evolution of \% inhibition vs electrolysis time (a) $\mathrm{pH} 3$ and (b) $\mathrm{pH} 6$ after (匹) 5 min and (•) 15 min of exposure to V. fischeri bacteria

The stability of the catalytic activity and reusability of the prepared $\mathrm{Fe}^{\mathrm{II}} \mathrm{Fe}^{\mathrm{III}} \mathrm{LDH} / \mathrm{CF}$ cathode for the mineralization and degradation of SMT solution at $\mathrm{pH} 6$ was shown in Fig. 10.The stability experiment was performed by replacing the used/treated solution by fresh SMT solution and mildly washing the $\mathrm{Fe}^{\mathrm{II}} \mathrm{Fe}^{\mathrm{III}} \mathrm{LDH} / \mathrm{CF}$ cathode after each cycle.Excellent reusability over 10 cycles of $4 \mathrm{~h}$ treatment was observed for both mineralization and degradation of SMT solution. The catalytic efficiency of $\mathrm{Fe}^{\mathrm{II}} \mathrm{Fe} \mathrm{e}^{\mathrm{III}} \mathrm{LDH} / \mathrm{CF}$ showed less than $17 \%$ reduction in term of TOC removal efficiency over 10 cycles of $4 \mathrm{~h}$ treatment (Fig. 10a), demonstrating the efficacy of the HEF process for treatment of SMT solution. Interestingly, complete degradation of $0.2 \mathrm{mM}$ SMT was always observed even after 10 cycles as depicted in Fig. 10b, indicating the high stability of the catalytic activity of the prepared cathode. Complete degradation of SMT was attained after $1 \mathrm{~h}$ of electrolysis for the first two cycles, whereas it requires over $2 \mathrm{~h}$ for the rest 
of the cycles, confirming the slight reduction in the catalytic activity of the cathode with reusability. As shown in Fig. 10a, the observed reduction in catalytic activity of the cathode over the 10 cycles was attributed to mechanical wearing of the LDH particles from the carbon-felt due to vigorous stirring, since the $\mathrm{LDH}$ is very stable at the working $\mathrm{pH}(\mathrm{pH} 6)$ as reported in Fig. $6 \mathrm{~b}$.
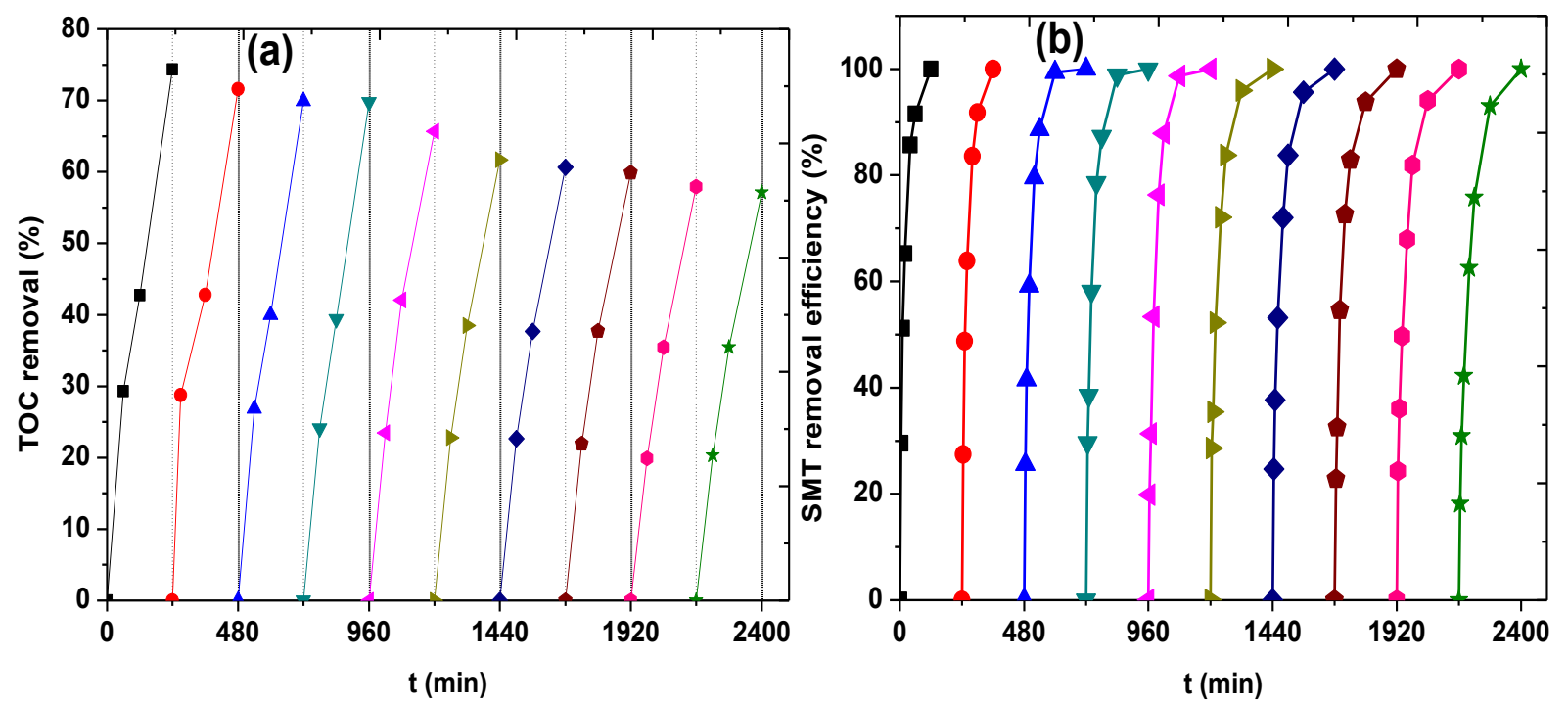

Figure 10: Reusability of $\mathrm{Fe}^{\mathrm{II}} \mathrm{Fe}^{\mathrm{III}} \mathrm{LDH} / \mathrm{CF}$ cathode at $\mathrm{pH} 6$ with cycle (a) $\mathrm{TOC}$ removal and (b) SMT removal efficiency during the treatment of $0.2 \mathrm{mM}$ SMT solution using $\mathrm{Fe}^{\mathrm{II}} \mathrm{Fe}^{\mathrm{III}} \mathrm{LDH} / \mathrm{CF}$ at $7.5 \mathrm{~mA} \mathrm{~cm}^{-2}$.

\subsection{Mechanism of mineralization of SMT at different $p H$}

According to the literature [11,13], two different situations may be encounteredduring HEF treatment depending on the $\mathrm{pH}$ of the treated solution and solubility of the solid Fe catalyst with $\mathrm{pH}$. At strong acidic $\mathrm{pH}$ (i.e. $\mathrm{pH} 3$ ), the production of ${ }^{\bullet} \mathrm{OH}$ seems to be controlled by redox cycling of dissolved $\mathrm{Fe}^{3+} / \mathrm{Fe}^{2+}$ resulting from the leaching of the $\mathrm{LDH}$ and surface $\mathrm{Fe} / \mathrm{II} / \mathrm{Fe}^{\mathrm{III}}$ at the 
surface of the LDH. As such the mineralization and degradation of the SMT at $\mathrm{pH} 3$ was a combined contribution of homogeneous and surface catalyzed (heterogeneous) processes, in addition to the oxidation by $\mathrm{Ti}_{4} \mathrm{O}_{7}\left({ }^{\bullet} \mathrm{OH}\right)$ generated at the surface of the anode via water oxidation irrespective of $\mathrm{pH}$. The in-situ $\mathrm{H}_{2} \mathrm{O}_{2}$ produced between the cathode and solution interface in acidic medium is catalytically decomposed to stronger oxidizing agent $\left({ }^{\bullet} \mathrm{OH}\right)$ by the surface bound $\equiv \mathrm{Fe}^{\mathrm{II}} / \mathrm{Fe}^{\mathrm{III}}$ or dissolved $\mathrm{Fe}^{3+} / \mathrm{Fe}^{2+}$ in the bulk.

In contrast, at neutral and basic $\mathrm{pH}\left(\mathrm{pH} 6\right.$ and 9), $\mathrm{H}_{2} \mathrm{O}_{2}$ activation was majorly by surface iron catalyzed process because LDH is almost insoluble at these pHs (Fig. 8b). HEF is a surfacecatalyzed process controlled by many parameters such as $\mathrm{H}_{2} \mathrm{O}_{2}$ concentration, solution $\mathrm{pH}$ and solid catalyst properties $[13,18]$. The kineticsand the reaction mechanism of the heterogeneous catalytic activation of $\mathrm{H}_{2} \mathrm{O}_{2}$ is not well-resolved in literature; however the formation of ${ }^{\bullet} \mathrm{OH}$ from catalytic activation of $\mathrm{H}_{2} \mathrm{O}_{2}$ by metal oxides is generally accepted as the most critical step in the entire oxidation process, which is similar to that of classical Fenton system as proposed by Harber-Weiss theory [13]. The ${ }^{\bullet} \mathrm{OH}$ formation in surface catalyzed process is initiated by interaction of $\mathrm{H}_{2} \mathrm{O}_{2}$ with the surface iron species like $\equiv \mathrm{Fe} \mathrm{e}^{\mathrm{III}}-\mathrm{OH}$ and its one-electron reduced form, $\equiv \mathrm{Fe}^{\mathrm{II}}-\mathrm{OH}$ (eq. 10), forming a surface complex of $\mathrm{H}_{2} \mathrm{O}_{2}, \equiv \mathrm{Fe}^{\mathrm{III}}-\mathrm{OH}\left(\mathrm{H}_{2} \mathrm{O}_{2}\right)_{\mathrm{s}}$ (eq. 11) at the inner and outer matrix of the carbon-felt $[13,18]$. The $\equiv \mathrm{Fe}^{\mathrm{III}}-\mathrm{OH}\left(\mathrm{H}_{2} \mathrm{O}_{2}\right)_{\mathrm{s}}$ complex may further undergo a reversible ground-state electron transfer (eq. 12) and activation (eq. 13) to form $\equiv \mathrm{Fe}^{\mathrm{II}-\mathrm{OH} \text { and } \mathrm{HO}_{2}}{ }^{\bullet}$. With the rapid consumption of $\mathrm{H}^{+}$in basic medium, the rate of eq. 13 and 14 can be significantly promoted, thus increasing the ${ }^{\bullet} \mathrm{OH}$ rate [13]. Beside, this could also explain the excellent mineralization of SMT observed at $\mathrm{pH} 6$ and 9. Accordingly, the $\equiv \mathrm{Fe}^{\mathrm{II}}-\mathrm{OH}$ catalyzes the activation of $\mathrm{H}_{2} \mathrm{O}_{2}$ to ${ }^{\bullet} \mathrm{OH}$ (eq. 14), which, along with $\mathrm{Ti}_{4} \mathrm{O}_{7}\left({ }^{\bullet} \mathrm{OH}\right)$ can mineralize SMT and its intermediates to $\mathrm{CO}_{2}$ and $\mathrm{H}_{2} \mathrm{O}$ (eq. 15). The ${ }^{\bullet} \mathrm{OH}$ produced may either react directly 
with SMT molecules (eq. 15) or quenched by $\mathrm{H}_{2} \mathrm{O}_{2}$ (eq. 16) to form weak oxidant $\mathrm{HO}_{2}{ }^{\bullet}$. As such, high mass transport of the organic molecules (stirring) is necessary to ensure maximum reaction of ${ }^{\bullet} \mathrm{OH}$ with organic pollutant as well as minimize the scavenging of the ${ }^{\bullet} \mathrm{OH}$.

$$
\begin{aligned}
& \equiv \mathrm{Fe}^{\mathrm{III}}-\mathrm{OH}+\mathrm{e}^{-} \rightarrow \equiv \mathrm{Fe}^{\mathrm{II}}-\mathrm{OH} \\
& \equiv \mathrm{Fe} \mathrm{eII}^{\mathrm{II}}-\mathrm{OH}+\mathrm{H}_{2} \mathrm{O}_{2} \leftrightarrow \equiv \mathrm{Fe}^{\mathrm{III}}-\mathrm{OH}\left(\mathrm{H}_{2} \mathrm{O}_{2}\right)_{(\mathrm{s})} \\
& \equiv \mathrm{Fe} e^{\mathrm{III}}-\mathrm{OH}\left(\mathrm{H}_{2} \mathrm{O}_{2}\right)_{(\mathrm{s})} \rightarrow \equiv \mathrm{Fe} \mathrm{F}^{\mathrm{II}}-\mathrm{OH}\left(\mathrm{HO}_{2}{ }^{\bullet}\right)_{(\mathrm{s})}+\mathrm{H}^{+} \\
& \equiv \mathrm{Fe}^{\mathrm{II}}-\mathrm{OH}\left(\mathrm{HO}_{2}^{\bullet}\right)_{(\mathrm{s})} \rightarrow \equiv \mathrm{Fe} \mathrm{e}^{\mathrm{II}}-\mathrm{OH}+\mathrm{HO}_{2}{ }^{\bullet}+\mathrm{H}^{+} \\
& \equiv \mathrm{Fe} e^{\mathrm{II}}-\mathrm{OH}+\mathrm{H}_{2} \mathrm{O}_{2} \rightarrow \equiv \mathrm{Fe} \mathrm{e}^{\mathrm{III}}-\mathrm{OH}+\bullet \mathrm{OH}+\mathrm{OH}^{-} \\
& \bullet{ }^{\bullet} \mathrm{OH} / \mathrm{Ti}_{4} \mathrm{O}_{7}\left({ }^{\bullet} \mathrm{OH}\right)+\mathrm{SMT} \rightarrow \mathrm{CO}_{2}+\mathrm{H}_{2} \mathrm{O} \\
& \bullet \cdot \mathrm{OH}+\mathrm{H}_{2} \mathrm{O}_{2} \rightarrow \mathrm{HO}_{2}^{\bullet}+\mathrm{H}_{2} \mathrm{O}
\end{aligned}
$$

\section{Conclusions}

The oxidative degradation of antibiotic SMT and mineralization of its aqueous solutionin both acidic and basic media by HEF system using $\mathrm{Fe}^{\mathrm{II}} \mathrm{Fe}^{\mathrm{III}}$ LDH/CF cathode was investigated. The $\mathrm{Fe}^{\mathrm{II}} \mathrm{Fe}^{\mathrm{III}} \mathrm{LDH}$ was grown on $\mathrm{CF}$ by solvothermal process and the structural, chemical and electrochemical characterization reveals highly crystalline and porous structure containing $\mathrm{FeOOH}$ and $\mathrm{Fe}_{2} \mathrm{O}_{3}$ as major secondary phase with enhanced conductivity. Excellent mineralization of SMT solutions was observed at all pHs studied with TOC removal of at least $90 \%$ attained after $8 \mathrm{~h}$ of treatment. In contrast, conventional $\mathrm{EF}$ with optimized quantity of $\mathrm{Fe}^{2+}$ as well as EO- $\mathrm{H}_{2} \mathrm{O}_{2}$ using raw CF cathode showed lower mineralization of SMT solutions at all 
the studied $\mathrm{pH}$ values in comparison to $\mathrm{HEF}$ with $\mathrm{Fe}^{\mathrm{II}} \mathrm{Fe}^{\mathrm{III}} \mathrm{LDH} / \mathrm{CF}$ cathode. The mineralization of SMT in HEF was by both $\mathrm{Fe}^{3+} / \mathrm{Fe}^{2+}$ redox homogeneous catalyzed and surface catalyzed processes at strong acidic $\mathrm{pH}(\mathrm{pH} 3)$, whereas surface catalyzed process was predominant at neutral or basic $\mathrm{pH}\left(\mathrm{pH} 6\right.$ and 9) along with the contribution of $\mathrm{Ti}_{4} \mathrm{O}_{7}(\bullet \mathrm{OH})$ generated at the anode surface irrespective of $\mathrm{pH}$. Catalytic activity of the prepared cathode was highly stable with negligible leaching at high $\mathrm{pH}$ and excellent reusability was achieved over 10 cycles of $4 \mathrm{~h}$ treatment. The initial SMT solution showed relatively high inhibition to $V$. fischeri bacteria but was totally detoxified to approximately zero percent inhibition after $8 \mathrm{~h}$ of treatment using $\mathrm{Fe}^{\mathrm{II}} \mathrm{Fe}^{\mathrm{III}} \mathrm{LDH} / \mathrm{CF}$ at $\mathrm{pH} 3$ as well as $\mathrm{pH}$ 6. SMT degradation was via the formation of several cyclic intermediates which were later mineralized to short-chain carboxylic acids as the final end organic byproducts in the treated solution. Based on identified intermediate products, a plausible

mineralization pathway is proposed. Finally at optimum conditions, effective decontamination of synthetic SMT solution could be achieved within 4-6 h electrolysis with minimized energy cost.

\section{ACKNOWLEDGEMENTs}

The authors thank the EU for providing financial support through the Erasmus Mundus Joint Doctorate Programme $\mathrm{ETeCoS}^{3}$ (Environmental Technologies for Contaminated Solids, Soils and Sediments, grant agreement FPA n²010-0009) and the ANR (French National Research Agency) funding through ANR ECO TS - CELectrON, (grant nº: ANR-13-ECOT-0003). 


\section{References}

[1] M. Panizza, G. Cerisola, Direct and mediated anodic oxidation of organic pollutants, Chem. Rev. 109 (2009) 6541-6569.

[2] E. Brillas, I. Sires, M.A. Oturan, Electro-Fenton process and related electrochemical technologies based on Fenton's reaction chemistry, Chem. Rev. 109 (2009) 6570-6631.

[3] M.A. Oturan, J.J. Aaron, Advanced oxidation processes in water/wastewater treatment: Principles and applications. A review, Crit. Rev. Environ. Sci. Technol. 44 (2014) 25772641.

[4] C.A. Martínez-Huitle, M.A. Rodrigo, I. Sirés, O. Scialdone, Single and coupled electrochemical processes and reactors for the abatement of organic water pollutants: A critical review, Chem. Rev. 115 (2015) 13362-13407.

[5] K.V. Plakas, A.J. Karabelas, Electro-Fenton applications in the water industry, in: Springer Berlin Heidelberg, Berlin, Heidelberg, 2017.

[6] M.A. Rodrigo, N. Oturan, M.A. Oturan, Electrochemically assisted remediation of pesticides in soils and water: A review, Chem. Rev. 114 (2014) 8720-8745.

[7] I. Sirés, E. Brillas, M.A. Oturan, M.A. Rodrigo, M. Panizza, Electrochemical advanced oxidation processes: today and tomorrow. A review, Environ. Sci. Pollut. Res. 21 (2014) $8336-8367$.

[8] S.O. Ganiyu, E.D. van Hullebusch, M. Cretin, G. Esposito, M.A. Oturan, Coupling of membrane filtration and advanced oxidation processes for removal of pharmaceutical residues: A critical review, Sep. Purif. Technol. 156 (2015) 891-914. 
[9] Z. Niu, Y. Wang, H. Lin, F. Jin, Y. Li, J. Niu, Electrochemically enhanced removal of perfluorinated compounds (PFCs) from aqueous solution by CNTs-graphene composite electrode, Chem. Eng. J. 328 (2017) 228-235.

[10] I. Sirés, E. Brillas, Remediation of water pollution caused by pharmaceutical residues based on electrochemical separation and degradation technologies: A review, Environ. Int. 40 (2012) 212-229.

[11] J. Li, Z. Ai, L. Zhang, Design of a neutral electro-Fenton system with $\mathrm{Fe} @ \mathrm{Fe}_{2} \mathrm{O}_{3} / \mathrm{ACF}$ composite cathode for wastewater treatment, J. Hazard. Mater. 164 (2009) 18-25.

[12] N. Qiao, H. Ma, M. Hu, Design of a neutral three-dimensional electro-Fenton system with various bentonite-based Fe particle electrodes: A comparative study, Mater. Res. Innov. 19 (2015) S2-137-S2-141.

[13] Y. Wang, G. Zhao, S. Chai, H. Zhao, Y. Wang, Three-dimensional homogeneous ferritecarbon aerogel: One pot fabrication and enhanced electro-Fenton reactivity, ACS Appl. Mater. Interfaces. 5 (2013) 842-852.

[14] S.O. Ganiyu, T.X. Huong Le, M. Bechelany, G. Esposito, E.D. van Hullebusch, M.A. Oturan, M. Cretin, A hierarchical CoFe-layered double hydroxide modified carbon-felt cathode for heterogeneous electro-Fenton process, J Mater Chem A. 5 (2017) 3655-3666.

[15] A. Özcan, A. Atılır Özcan, Y. Demirci, E. Şener, Preparation of $\mathrm{Fe}_{2} \mathrm{O}_{3}$ modified kaolin and application in heterogeneous electro-catalytic oxidation of enoxacin, Appl. Catal. B Environ. 200 (2017) 361-371.

[16] L. Labiadh, M.A. Oturan, M. Panizza, N.B. Hamadi, S. Ammar, Complete removal of AHPS synthetic dye from water using new electro-fenton oxidation catalyzed by natural pyrite as heterogeneous catalyst, J. Hazard. Mater. 297 (2015) 34-41. 
[17] N. Barhoumi, H. Olvera-Vargas, N. Oturan, D. Huguenot, A. Gadri, S. Ammar, E. Brillas, M.A. Oturan, Kinetics of oxidative degradation/mineralization pathways of the antibiotic tetracycline by the novel heterogeneous electro-Fenton process with solid catalyst chalcopyrite, Appl. Catal. B Environ. 209 (2017) 637-647.

[18] G. Zhang, Y. Zhou, F. Yang, FeOOH-catalyzed heterogeneous electro-Fenton system upon anthraquinone@Graphene nanohybrid cathode in a divided electrolytic cell: Catholyteregulated catalytic oxidation performance and mechanism, J. Electrochem. Soc. 162 (2015) H357-H365.

[19] C.M. Sánchez-Sánchez, E. Expósito, J. Casado, V. Montiel, Goethite as a more effective iron dosage source for mineralization of organic pollutants by electro-Fenton process, Electrochem. Commun. 9 (2007) 19-24.

[20] W.R.P. Barros, J.R. Steter, M.R.V. Lanza, A.C. Tavares, Catalytic activity of Fe3-xCuxO4 $(0 \leq x \leq 0.25)$ nanoparticles for the degradation of Amaranth food dye by heterogeneous electro-Fenton process, Appl. Catal. B Environ. 180 (2016) 434-441.

[21] O. Iglesias, M.A.F. de Dios, T. Tavares, M.A. Sanromán, M. Pazos, Heterogeneous electroFenton treatment: preparation, characterization and performance in groundwater pesticide removal, J. Ind. Eng. Chem. 27 (2015) 276-282.

[22] C. Zhang, M. Zhou, G. Ren, X. Yu, L. Ma, J. Yang, F. Yu, Heterogeneous electro-Fenton using modified iron-carbon as catalyst for 2,4-dichlorophenol degradation: Influence factors, mechanism and degradation pathway, Water Res. 70 (2015) 414-424.

[23] S.B. Hammouda, F. Fourcade, A. Assadi, I. Soutrel, N. adhoum, A. Amrane, L. Monser, Effective heterogeneous electro-Fenton process for the degradation of a malodorous 
compound, indole, using iron loaded alginate beads as a reusable catalyst, Appl. Catal. B Environ. 182 (2016) 47-58.

[24] J. Ramírez, L.A. Godínez, M. Méndez, Y. Meas, F.J. Rodríguez, Heterogeneous photoelectro-Fenton process using different iron supporting materials, J. Appl. Electrochem. 40 (2010) 1729-1736.

[25] H. Zhao, Y. Chen, Q. Peng, Q. Wang, G. Zhao, Catalytic activity of MOF(2Fe/Co)/carbon aerogel for improving $\mathrm{H} 2 \mathrm{O} 2$ and $\mathrm{OH}$ generation in solar photo-electro-Fenton process, Appl. Catal. B Environ. 203 (2017) 127-137.

[26] H. Zhao, L. Qian, X. Guan, D. Wu, G. Zhao, Continuous bulk FeCuC aerogel with ultradispersed metal nanoparticles: An efficient 3D heterogeneous electro-Fenton cathode over a wide range of pH 3-9, Environ. Sci. Technol. 50 (2016) 5225-5233.

[27] H. Zhao, L. Qian, Y. Chen, Q. Wang, G. Zhao, Selective catalytic two-electron $\mathrm{O}_{2}$ reduction for onsite efficient oxidation reaction in heterogeneous electro-Fenton process, Chem. Eng. J. 332 (2018) 486-498.

[28] Y. Wang, H. Zhao, G. Zhao, Highly Ordered Mesoporous $\mathrm{Fe}_{3} \mathrm{O}_{4} @$ Carbon Embedded Composite: High Catalytic Activity, Wide pH Range and Stability for Heterogeneous Electro-Fenton, Electroanalysis. 28 (2016) 169-176..

[29] E.G. Garrido-Ramírez, M.L. Mora, J.F. Marco, M.S. Ureta-Zañartu, Characterization of nanostructured allophane clays and their use as support of iron species in a heterogeneous electro-Fenton system, Appl. Clay Sci. 86 (2013) 153-161.

[30] L. Liang, Y. An, M. Zhou, F. Yu, M. Liu, G. Ren, Novel rolling-made gas-diffusion electrode loading trace transition metal for efficient heterogeneous electro-Fenton-like, J. Environ. Chem. Eng. 4 (2016) 4400-4408. 
[31] A. Dirany, I. Sirés, N. Oturan, M.A. Oturan, Electrochemical abatement of the antibiotic sulfamethoxazole from water, Chemosphere 81 (2010) 594-602.

[32] Y. Huang, T. Zhou, X. Wu, J. Mao, Efficient sonoelectrochemical decomposition of sulfamethoxazole adopting common Pt/graphite electrodes: The mechanism and favorable pathways, Ultrason. Sonochem. 38 (2017) 735-743.

[33] T.A. Ternes, Occurrence of drugs in German sewage treatment plants and rivers: Dedicated to Professor Dr. Klaus Haberer on the occasion of his 70th birthday.1, Water Res. 32 (1998) $3245-3260$.

[34] O. Frédéric, P. Yves, Pharmaceuticals in hospital wastewater: Their ecotoxicity and contribution to the environmental hazardous of the effluent, Chemosphere 115 (2014) 3139.

[35] H. Lin, J. Niu, J. Xu, Y. Li, Y. Pan, Electrochemical mineralization of sulfamethoxazole by $\mathrm{Ti} / \mathrm{SnO} 2-\mathrm{Sb} / \mathrm{Ce}-\mathrm{PbO} 2$ anode: Kinetics, reaction pathways, and energy cost evolution, Electrochimica Acta. 97 (2013) 167-174.

[36] N. Oturan, S.O. Ganiyu, S. Raffy, M.A. Oturan, Sub-stoichiometric titanium oxide as a new anode material for electro-Fenton process: Application to electrocatalytic destruction of antibiotic amoxicillin, Appl. Catal. B Environ. 217 (2017) 214-223.

[37] A.M. Zaky, B.P. Chaplin, Porous substoichiometric $\mathrm{TiO}_{2}$ anodes as reactive electrochemical membranes for water treatment, Environ. Sci. Technol. 47 (2013) 65546563.

[38] S.O. Ganiyu, N. Oturan, S. Raffy, G. Esposito, E.D. van Hullebusch, M. Cretin, M.A. Oturan, Use of sub-stoichiometric titanium oxide as a ceramic electrode in anodic oxidation 
and electro-Fenton degradation of the beta-blocker propranolol: Degradation kinetics and mineralization pathway, Electrochimica Acta. 242 (2017) 344-354.

[39] J. Zhao, J. Chen, S. Xu, M. Shao, D. Yan, M. Wei, D.G. Evans, X. Duan, CoMn-layered double hydroxide nanowalls supported on carbon fibers for high-performance flexible energy storage devices, J. Mater. Chem. A. 1 (2013) 8836.

[40] X. Cai, X. Shen, L. Ma, Z. Ji, C. Xu, A. Yuan, Solvothermal synthesis of NiCo-layered double hydroxide nanosheets decorated on RGO sheets for high performance supercapacitor, Chem. Eng. J. 268 (2015) 251-259.

[41] Y. Han, Z.-H. Liu, Z. Yang, Z. Wang, X. Tang, T. Wang, L. Fan, K. Ooi, Preparation of $\mathrm{Ni}^{2+}-\mathrm{Fe}^{3+}$ layered double hydroxide material with high crystallinity and well-defined hexagonal shapes, Chem. Mater. 20 (2008) 360-363.

[42] M. Griffing, M.G. Mellon, Colorimetric determination of iron with various dioximes, Anal. Chem. 19 (1947) 1017-1020.

[43] S.O. Ganiyu, N. Oturan, S. Raffy, M. Cretin, R. Esmilaire, E. van Hullebusch, G. Esposito, M.A. Oturan, Sub-stoichiometric titanium oxide $\left(\mathrm{Ti}_{4} \mathrm{O}_{7}\right)$ as a suitable ceramic anode for electrooxidation of organic pollutants: A case study of kinetics, mineralization and toxicity assessment of amoxicillin, Water Res. 106 (2016) 171-182.

[44] T.X.H. Le, T.V. Nguyen, Z. Amadou Yacouba, L. Zoungrana, F. Avril, D.L. Nguyen, E. Petit, J. Mendret, V. Bonniol, M. Bechelany, S. Lacour, G. Lesage, M. Cretin, Correlation between degradation pathway and toxicity of acetaminophen and its by-products by using the electro-Fenton process in aqueous media, Chemosphere. 172 (2017) 1-9. 
[45] G. Nagaraju, G.S.R. Raju, Y.H. Ko, J.S. Yu, Hierarchical Ni-Co layered double hydroxide nanosheets entrapped on conductive textile fibers: a cost-effective and flexible electrode for high-performance pseudocapacitors, Nanoscale. 8 (2016) 812-825.

[46] Q. Wang, S. Tian, J. Long, P. Ning, Use of Fe(II)Fe(III)-LDHs prepared by co-precipitation method in a heterogeneous-Fenton process for degradation of Methylene Blue, Catal. Today. 224 (2014) 41-48.

[47] X. Long, Z. Wang, S. Xiao, Y. An, S. Yang, Transition metal based layered double hydroxides tailored for energy conversion and storage, Mater. Today. 19 (2016) 213 - 226.

[48] Y. Li, L. Zhang, X. Xiang, D. Yan, F. Li, Engineering of ZnCo-layered double hydroxide nanowalls toward high-efficiency electrochemical water oxidation, J. Mater. Chem. A. 2 (2014) 13250.

[49] T.X.H. Le, M. Bechelany, S. Lacour, N. Oturan, M.A. Oturan, M. Cretin, High removal efficiency of dye pollutants by electron-Fenton process using a graphene based cathode, Carbon. 94 (2015) 1003-1011.

[50] P. Geng, J. Su, C. Miles, C. Comninellis, G. Chen, Highly-ordered Magnéli $\mathrm{Ti}_{4} \mathrm{O}_{7}$ nanotube arrays as effective anodic material foreElectro-oxidation, Electrochimica Acta. 153 (2015) $316-324$.

[51] D. Bejan, J.D. Malcolm, L. Morrison, N.J. Bunce, Mechanistic investigation of the conductive ceramic Ebonex ${ }^{\circledR}$ as an anode material, Electrochimica Acta. 54 (2009) 55485556.

[52] N. Oturan, J. Wu, H. Zhang, V.K. Sharma, M.A. Oturan, Electrocatalytic destruction of the antibiotic tetracycline in aqueous medium by electrochemical advanced oxidation processes: Effect of electrode materials, Appl. Catal. B Environ. 140-141 (2013) 92-97. 
[53] A. Dirany, I. Sirés, N. Oturan, A. Özcan, M.A. Oturan, Electrochemical treatment of the antibiotic sulfachloropyridazine: Kinetics, reaction pathways, and toxicity evolution, Environ. Sci. Technol. 46 (2012) 4074-4082.

[54] E. Brillas, S. Garcia-Segura, M. Skoumal, C. Arias, Electrochemical incineration of diclofenac in neutral aqueous medium by anodic oxidation using Pt and boron-doped diamond anodes, Chemosphere. 79 (2010) 605-612.

[55] A. Özcan, Y. Şahin, A.S. Koparal, M.A. Oturan, A comparative study on the efficiency of electro-Fenton process in the removal of propham from water, Appl. Catal. B Environ. 89 (2009) 620-626.

[56] M.A. Oturan, M. Pimentel, N. Oturan, I. Sirés, Reaction sequence for the mineralization of the short-chain carboxylic acids usually formed upon cleavage of aromatics during electrochemical Fenton treatment, Electrochimica Acta. 54 (2008) 173-182.

[57] S. Garcia-Segura, E. Brillas, Mineralization of the recalcitrant oxalic and oxamic acids by electrochemical advanced oxidation processes using a boron-doped diamond anode, Water Res. 45 (2011) 2975-2984.

[58] S.H. Li, D. Bejan, M.S. Mcdowell, N.J. Bunce, Mixed first and zero order kinetics in the electrooxidation of sulfamethoxazole at a boron-doped diamond (BDD) anode, J. Appl. Electrochem. 38 (2008) 151-159.

[59] A. Dirany, S. Efremova Aaron, N. Oturan, I. Sirés, M.A. Oturan, J.J. Aaron, Study of the toxicity of sulfamethoxazole and its degradation products in water by a bioluminescence method during application of the electro-Fenton treatment, Anal. Bioanal. Chem. 400 (2010) 353-360. 